Illinois State University

ISU ReD: Research and eData

Theses and Dissertations

3-28-2017

\title{
And That's The Word: Effects Of The Colbert Report On Political Knowledge And Participation
}

Nicholas Anthony Canfield

Illinois State University, nickcanfield29@gmail.com

Follow this and additional works at: https://ir.library.illinoisstate.edu/etd

Part of the Communication Commons, and the Political Science Commons

\section{Recommended Citation}

Canfield, Nicholas Anthony, "And That's The Word: Effects Of The Colbert Report On Political Knowledge And Participation" (2017). Theses and Dissertations. 748.

https://ir.library.illinoisstate.edu/etd/748

This Thesis is brought to you for free and open access by ISU ReD: Research and eData. It has been accepted for inclusion in Theses and Dissertations by an authorized administrator of ISU ReD: Research and eData. For more information, please contact ISUReD@ilstu.edu. 


\title{
AND THAT'S THE WORD: EFFECTS OF THE COLBERT REPORT ON POLITICAL KNOWLEDGE AND PARTICIPATION
}

\author{
Nicholas Anthony Canfield
}

71 Pages

The Colbert Report was a satirical, political, and "fake" news show that lasted for almost a decade on the Comedy Central Network. Although many scholars have argued the program was less impactful and influential than Jon Stewart's The Daily Show, phenomena such as the "Colbert Bump" show a definite impact on the political lives of many Americans. Using four quantitative surveys from 2008 to 2012, this thesis investigates the effects of watching The Colbert Report on individuals' political knowledge and political participation. Results indicate non-Republican viewers increased their political knowledge, but not participation, from watching the show. The educational effect was more prevalent than The Daily Show and other political news programs. Results indicate a divide based on partisanship regarding how media educates and incentivizes participation in politics.

KEYWORDS: Political Satire, Political Humor, Stephen Colbert, The Colbert Report, Political Knowledge, Political Participation, Democracy, Media, Stevenson Center. 
AND THAT'S THE WORD: EFFECTS OF THE COLBERT REPORT ON POLITICAL KNOWLEDGE AND PARTICIPATION

NICHOLAS ANTHONY CANFIELD

A Thesis Submitted in Partial

Fulfillment of the Requirements for the Degree of

\section{MASTER OF SCIENCE}

Department of Politics and Government

ILLINOIS STATE UNIVERSITY 
(C) 2017 Nicholas Anthony Canfield 
AND THAT'S THE WORD: EFFECTS OF THE COLBERT REPORT ON POLITICAL KNOWLEDGE AND PARTICIPATION

NICHOLAS ANTHONY CANFIELD

COMMITTEE MEMBERS:

Carl Palmer, Chair

T.Y. Wang

Kerri Milita 


\section{ACKNOWLEDGMENTS}

I would like to first and foremost thank my family and friends for putting up with me constantly talking about this work. They have supported me through this thesis and my entire graduate career, and this work would not be possible if it were not for them. I am also indebted to the kind and wonderful mentors of Dr. Palmer, Dr. Wang, and Dr. Milita for guiding me through this research and for allowing me to engage in this important area of study, especially in today's "alternative" political reality. Lastly, I would like to dedicate this thesis to Stephen Colbert and his legacy on The Colbert Report. There is a void in American political discourse left by his satirical absence, and one can only hope that either he or someone else is brave enough to man this lighthouse in these darkest days of our American Experience.

N. A. C. 


\section{CONTENTS}

\section{Page}

ACKNOWLEDGMENTS

CONTENTS

ii

TABLES

iv

FIGURES

$\mathrm{V}$

CHAPTER

\section{INTRODUCTION}

II. LITERATURE REVIEW

The Importance of Political Knowledge and Participation 5

$\begin{array}{ll}\text { Political Knowledge } & 6\end{array}$

Political Participation $\quad 9$

Effects of Political Media Consumption $\quad 12$

$\begin{array}{ll}\text { Theories and Demand of Political Humor } & 13\end{array}$

Effects of Political Humor 15

Theoretical Importance and Effects of TCR 16

Gaps in Research 18

III. HYPOTHESES AND METHODOLOGY 21

Hypotheses $\quad 21$

Dependent Variables $\quad 24$

Independent Variable $\quad 27$

Control Variables $\quad 29$

$\begin{array}{ll}\text { Methodology } & 30\end{array}$

IV. POLITICAL KNOWLEDGE RESULTS AND DISCUSSION 31

V. POLITICAL PARTICIPATION RESULTS AND DISCUSSION 42

VI. INFORMED OR ACTIVE: CHOOSE ONE 49 
VII. CONCLUSION

$\begin{array}{lc}\text { REFERENCES } & 54\end{array}$

APPENDIX A. EGSS4 CODING

APPENDIX B. PEW MCS 2008 CODING 67

$\begin{array}{ll}\text { APPENDIX C. PEW MCS } 2010 \text { CODING } & 68\end{array}$

APPENDIX D. PEW MCS 2012 CODING 69

APPENDIX E. ALL PEW MCS CONTROL VARIABLES CODING 70 


\section{TABLES}

Table $\quad$ Page

$\begin{array}{ll}\text { 1. Surveys } & 23\end{array}$

2. Political Knowledge Scores 25

3. Political Participation Scores 26

4. Watching TCR 27

5. Frequency of Watching 28

6. The Power of "Truthiness" on Political Knowledge 32

7. Knowledge Effects Skew Towards Independents and Democrats 38

8. The Null Effects of TCR on Political Participation 43

9. The Effects of TCR on Forms of Political Participation 45 


\section{FIGURES}

Figure $\quad$ Page

1. A Rise in Truthiness 33 


\section{CHAPTER I. INTRODUCTION}

Humor has always been a way to break down the rough boundaries of discussing and reviewing political life. Since the time of the ancient Greeks, political humor has been used to entertain viewers while critiquing political leaders, social conventions, and authorities. Of course, political humor has changed since the time of the Greeks, but its general function has remained the same (Schutz, 1977). Political cartoons, radio broadcasts, and television programs now can reach multitudes of people instantly and influence what and how they think. From Saturday Night Live to South Park, or The Onion to Between Two Ferns, many players are currently in this space, carving out market share and reaching out to new viewers across the United States and the world. No matter the form of its delivery, nor the importance it has been given, political humor has always played an interesting and powerful role in many societies' political histories. Recently, "fake news" shows like The Colbert Report, henceforth TCR, have enriched the field of political humor through its unique mixture of educational and entertaining programming.

TCR aired weekly on the television network Comedy Central from 2005 to 2014. It featured Stephen Colbert as a conservative political pundit based somewhat on Bill O'Reilly ${ }^{1}$ from Fox News' show The O'Reilly Factor. While Colbert would state that education was not the main goal of his show's many political stunts and that he was purely an entertainer (Mcgrath, 2012), many have posed the question of how much influence Colbert had on his audience and the American political system. Although previous work has examined the effects of political humor, Colbert's show brings serious questions to the discussion because of its unique style and position.

\footnotetext{
${ }^{1}$ O'Reilly was adoringly referred to as "Papa Bear" by Stephen.
} 
$T C R$ is seen as a new kind of political satire, due to its use of dual implicit and explicit messages, that delves away from the styles of former political satirists like Jay Leno and David Letterman (Baumgartner \& Morris, 2008). For example, a typical Colbert play was to criticize Democratic President Barack Obama's political successes in such a ridiculous manner that the only interpretation could be implicit support for Obama. In this example the direct and explicit message is "Obama is doing a bad job", but the intended implicit message is "Obama is doing a good job". Although one might believe this incongruence in messaging would prove ineffective, Colbert's style was quite brilliant, as both conservatives and liberals enjoyed the show and interpreted it through their own political lenses (Gaines, 2007; Baumgartner \& Morris, 2008). In social science literature, this seeing what one wants to see is referred to as motivated reasoning.

Through motivated reasoning, $T C R$ viewers most likely saw and processed messages that were congruent with their previously formed political beliefs (Lodge \& Taber, 2000). Conservatives saw Colbert's direct conservative messages while liberals only processed the implicit liberal ones because each group was actively seeking out entertainment and political news congruent with their beliefs. Even if viewers did take seriously Colbert's inconsistent message, this even could strengthen their already formed beliefs by causing them to search their memories for consistent information to balance out Colbert's opposing message (Redlawsk, 2002). Because of this ability to have two messages at one time through satire, Colbert's style was a direct contrast with his counterpart on the same network, Jon Stewart on The Daily Show. Even though Stewart would sometimes delve into satire, he was known for his use of stirring monologues and funny commentary mostly performed in an explicit manner with a direct and left leaning message. There were very few implicit messages targeted towards conservatives in Stewart's show, and therefore his ability to reach and influence conservative viewers was 
quite less than TCR. Colbert's stronger pull towards conservatives through his show is evident in a slightly higher percentage of total viewers identifying as Republicans in 2012 than The Daily Show (Pew Research Center, 2012). Unlike Stewart's more explicit messaging, Colbert always performed in his satirical character never explicitly informing his audience of his intended liberal messages; however, it is clear that Stephen Colbert was just the opposite of the right-wing conservative he portrayed.

Perhaps because of this unique and appealing satirical style, $T C R$ had a large viewership, with one academic survey from February 2007 showing 12 percent of young adults watching it for their source of news (Lewis, 2008). With such a large viewership receiving political news from $T C R$, there existed a large potential to significantly impact the political knowledge and engagement of its viewership. If such an effect did occur, one must ask how much more impactful was TCR over other sources of news? Was there something about the show's style that caused it to be an effective political motivator and educator? This study hypothesizes that watching TCR had a significant and positive effect on both political knowledge and participation because the program effectively educated and evoked political engagement through a type of politically engaging satire. Although one might believe this to be solely a historical analysis no longer relevant because TCR's final episode occurred in December 2014, this study still holds an important discussion due to the continued use of humor and satire in other political shows such as Last Week Tonight with John Oliver and The Daily Show with Trevor Noah. If TCR was an effective educator and political motivator, one should be able to identify what benefits society has lost with the absence of the program. Finally, this research maintains relevance because it analyzes ways the ways in which political news media can increase some of the most democratic principles for democracies, especially the United States. 
As Delli Carpini and Keeter state in the preface to their book What Americans Know About Politics and Why It Matters, “... an informed citizenry is a common thread that implicitly ties together all theories of democracy. [There is] consistent support for the idea that given the appropriate information, citizens are capable of making rational political choices.” (Delli Carpini \& Keeter, 1996, xii). A politically engaged and knowledgeable public is important to the most basic functioning and maintenance of democratic principles. If the public is not informed nor motivated to participate in politics, it will not be able to act towards its own self-interest. Determining which factors can increase political knowledge and participation is important because it can help many political groups, from policy makers to activists, accomplish their varied goals. This being so, determining if $T C R$ positively affected these factors is a theoretically important study not just for individual Americans; it is important for democracy and the entire American political system. 


\section{CHAPTER II. LITERATURE REVIEW}

\section{The Importance of Political Knowledge and Participation}

In short, the consensus about Americans' knowledge of and participation in politics is as consistent as it is bleak; sadly, Americans do not spend much effort on politics compared to people in other countries (Wolfinger \& Rosenstone, 1980). Since this was studied in the middle of the $20^{\text {th }}$ century with the seminal work of The American Voter (Campbell et al. 1960), it has been shown that only a small percentage of Americans can be described as sophisticated in their levels of political thinking. Even in the face of a dramatically different societal context in the $21^{\text {st }}$ century, the means by which voters ultimately decide their voting choices has not changed since the 1960's (Lewis-Beck, 2008). America has gained more political sophisticates since the 1960's (Lewis-Beck, 2008), but the overall level of American political sophistication is still quite low. To give some current examples, a large percentage of Americans cannot correctly identify which political party currently has majority control in Congress (Annenberg Public Policy Center, 2014), and voter turnout has been steadily decreasing with levels currently hovering between $50 \%$ to $60 \%$ for presidential elections and even lower for midterm, state, and local elections (FairVote, 2016). This is troublesome for democratic success. When $65 \%$ of Americans cannot name at least one of their political representatives (Mendes, 2013), how can they hold them accountable and make informed political decisions?

For these reasons, political knowledge and participation are important characteristics which affect all aspects of American political life; this work will address how political media can raise Americans' low levels of political sophistication. The United States suffers a case of a "paradox of modern democracy"; the informed and participatory citizenry for which it was constructed is not present (Delli Carpini \& Keeter, 1996). There exist many prescriptions and 
philosophies in political literature that try to fix, and sometimes even justify, these low levels of political sophistication, but it is a multi-sided battle. Political knowledge and political participation are intertwined with societal political sophistication, and both will be used as the outcome variables of this study. As Luskin (1990) claims, three factors must be studied to understand how publics do or do not become politically sophisticated: exposure to political information, ability to synthesize and organize that information, and the motivational forces behind them. Once there is an understanding of how individuals know what they know, why they act the way they act, and how media can play a role in these political efforts, predictions can be made about how individuals and publics can become more politically sophisticated.

\section{Political Knowledge}

Obtaining facts about politics is one of the necessary conditions for democracy to function by and for the people. This study will utilize Delli Carpini and Keeter's (1996, p. 10) definition of political knowledge as "the range of factual information about politics that is stored in long-term memory". Without a broad base of political knowledge across a citizenry, democratic accountability would appear impossible, and it would allow representatives the ability to not faithfully represent their constituents (Hutchings, 2003). In addition to the public good of a government that is accountable to its citizens, it is unlikely for individual constituents to take coherent and intelligent positions on issues when they are politically uninformed.

As Zaller (1992) demonstrates, politically aware individuals are able to hold more considerations and thoughts about political topics in their minds at one time; these individuals are also better able to state opinions that are more ideologically consistent with their predispositions than politically unaware people. Most importantly, knowledgeable citizens can make political decisions that are congruent with their values (Delli Carpini \& Keeter, 1996). 
When voting for political candidates, increasing one's knowledge about the candidates can help citizens vote more "correctly" towards their ideological views (Lau \& Redlawsk, 1997).

Knowledgeable citizens are also more likely to hold these consistent political attitudes over time, participate in the political process, and be more tolerant towards others' views (Delli Carpini \& Keeter, 1996). To affect citizens' voting behavior, citizens must first become aware of an issue, have previous knowledge of and engagement with it, and understand what the main political parties say about it (Campbell et al. 1960). These three conditions reinforce the need for certain levels of political knowledge in order for citizens to make informed votes. Some might say these conditions can be skirted by cues and heuristics (Lupia, 1994; Gilens \& Murakawa, 2002), but unfortunately many are not even able to obtain the basic and minimal levels of information to even approach being considered politically sophisticated.

Low levels of political knowledge maintain social inequality, therefore effective distribution of political knowledge can help many groups achieve better footing in all aspects of life. Groups in the US that are low in political knowledge such as young, female, and non-white citizens are not able to demand equal representation like their more represented older, white, and male counterparts (Delli Carpini \& Keeter, 1996) which translates to unequal distribution of benefits. This can be clearly shown by Congress frequently catering its political decisions and policies to benefit Whites more than African Americans and Latinos who have lower levels of political knowledge (Griffin \& Newman, 2008). This unequal distribution of political capital is also seen for citizens with no time or money to spend on becoming politically informed, and studies show that poor citizens are less likely to have their political opinions reflected in the voting behavior of their representatives (Bartels, 2009). Political knowledge is one of many 
gateways for many low-power groups to gain equal access to social resources and power; however, it is an extremely difficult hurdle to overcome.

As Delli Carpini and Keeter (1996) argue, minimally informed groups' access to political knowledge is limited because of their lower ability to attain their goals in the political arena, and this inability to accomplish political goals in turn has a reciprocal effect by lowering their political engagement and knowledge. If this chicken-or-the-egg problem were to be broken with structural changes, including better education through the media, more political and social equality would most likely follow (Delli Carpini \& Keeter, 1996). Drawing on economic thought, "[i]nformation operates like a rising tide that lifts all boats" (Gronke, 2000, p. 109), and this rising tide can maintain the functionality and accountability of democracies in addition to decreasing intergroup inequality. Although normatively the ideal of widespread political knowledge would find little disagreement, scholars debate about the level of specific information necessary for democratic governance to continue.

Even though the American populace may be politically uninformed, it has been shown that heuristics and institutions (such as party labels and political endorsements) can replace traditional political knowledge and help citizens make informed decisions (Mondak, 1993; Gordon \& Segura, 1997; Lau \& Redlawsk, 2001; Kinder \& Kiewiet, 1981; Druckman, 2001a, b). Societies can also compensate for a lack of political knowledge. "[R]egardless of citizens' levels of factual knowledge about politics, there are institutions embedded in our political system that may help citizens to assess the veracity of political actors' statements and to learn from them," (Boudreau, 2009, p. 288). Changing the conditions under which information is presented can compensate for a lack of political knowledge (Boudreau, 2009). Per this camp of scholars, American democracy can function even in the face of an uninformed public; however, given that 
increased political sophistication is an important variable which can affect many facets of individual behavior (Zaller, 1992), high levels of political knowledge should be an overall goal for which democracies should strive. Becoming informed about politics is only a start towards better democratic governance and accountability. To be useful in the democratic process, citizens must act on such correct information in order to benefit themselves individually and collectively in their groups.

\section{Political Participation}

Democratic theory over the centuries has held a mixed importance of the role of citizen participation in politics. The early founders of the US Constitution foresaw both the positives and dangers of a fully engaged citizenry, and more recent political theorists have also battled with this essential debate (Ekman \& Amnå, 2012; Dahlgren, 2013). For the American context, one in which citizens have increasingly disassociated themselves from political institutions like voting, it is difficult to argue against incentivizing citizens' political participation due to such current low rates (Putnam, 2000). It is with this light that many scholars have become heavy advocates for political participation and its many different forms. The most common forms of political participation which gather the attention of political scientists are conventional electoral behaviors like voting and attending political meetings (Campbell et al. 1954) and nonconventional activities such as protesting and violent action (Sabucedo \& Arce, 1991). Because there exist many definitions of political participation, this research will utilize a very inclusive definition created by Conge (1988, p. 247) of "individual or collective action at the national or local level that supports or opposes state structures, authorities, and/or decisions regarding allocation of public goods." As such, political participation may include verbal or non-verbal expression, violent or non-violent action, and a variety of intensity (Conge, 1988). The positives 
of engaging in many different types of political behavior ranging from rioting to checking politicians' Twitter accounts can be shown to have both individual and societal benefits.

Participatory democracy scholars argue that individuals can greatly benefit their personal development both politically and morally through increased political action (Pateman, 1970; Mason, 1982). Political participation can develop more responsible political behaviors, more intelligent social behaviors, and even more agreement and support towards democracy as a whole (Pateman, 1970; Finkel, 1987). Studies also show that political participation increases individuals' levels of external political efficacy, making them more likely to trust political authorities and believe that their government is responsive to their desires (Balch, 1974; Shaffer, 1981). Internal efficacy, the feeling of understanding and having an impact on politics, has also been shown to be slightly increased by political participation (Finkel, 1985), and a reciprocal effect between participation and external efficacy, the belief that the government will respond to citizens' demands, is seen on a stronger scale (Finkel, 1985; Finkel, 1987). This indicates that participation in politics can have a large impact on how people form their political opinions and support for government systems at large, and these factors can then reciprocally influence further political action.

On a societal level, the aggregate of individuals' political participation has various positive effects for a democratic system. Regime stability and legitimacy can be strengthened when citizens engage more with the political system (Ginsberg, 1982), and with political stability can come increased confidence in economic systems. On a more basic level and perhaps quite obviously, increased participation such as voting, campaigning, and interacting with public officials correlates with higher levels of democracy seen in measures like Vanhanen's Index of Democracy (Booth \& Richard, 1998). However, not only do systems become more democratic 
with more participation, but democracies' governance also improves. General governmental effectiveness, control of corruption, and consistency in good governmental management are all positively correlated with higher levels of political participation (Nekola, 2006). If stronger and more effective democracy is considered a positive, as most would see it, then it is hard to argue against attempts at increasing voter turnout, membership in political groups, and interaction between citizens and elected officials for the United States.

Through the belief that more political participation and greater political knowledge are normative goods for society this paper will view the American political context. This paper will not argue that perfect political participation across all forms is a goal, nor even possible; rather, it will argue that increasing American's already low numbers of political engagement to levels of other consolidated democratic countries should be a desirable goal. Maximizers of the aggregate societal benefit should look to increase both of these characteristics in individuals and political organizations. Thousands of political organizations already are making strides to stimulate Americans' political engagement, and one of the main institutions through which these campaigns are accomplished is the media.

Media, and especially political media, has an essential role in incentivizing Americans to learn about and engage in politics. It is a dominant force which cannot be underscored enough in the conversation of increasing political engagement in the United States. In a sense, the fate of American democracy depends on the successful transmission of knowledge on a mass scale between those who govern and those who are governed. Political media can bring down dictatorships, rally support for wars, and tarnish public officials with nothing more than a single tweet. Most importantly for this study, much literature has shown that what citizens know and 
how they behave in the political sphere largely depend upon what they learn from political media.

\section{Effects of Political Media Consumption}

Who benefits from media consumption and how it impacts them have always been important motifs in the communications literature. According to the Propaganda Model

formulated by Herman and Chomsky (2002), "the media serve and propagandize on behalf of the powerful societal interests that control and finance them". This is congruent with the work on public opinion conducted by Zaller (1992) which states that public opinion is dominated and controlled by elite discourse and goals in society. Per these two authors' models, any effects that media consumption (and, as is the focus of this project, political humor) have on viewers is an effort by elites to influence behavior and opinions. It has been shown that while news may be critical of elite dialogue, studies have repeatedly shown that political media is constrained in its expression as predicted by the Propaganda Model (Boyd-Barrett, 2004; Anderson \& Kincaid, 2013). Political elites limit how political media present and discuss content and views, and they do this to enhance their political goals. This constrained discourse limits the amount of political knowledge that is vital for democracy (Hutchings, 2003). Some clear examples of this bounded expression are the lack of US media coverage of the genocide in East Timor from 1977 to 1999 and the media's failure to question the legality of the Vietnam War (Herman \& Chomsky, 2002). Although elites have the potential to influence many with mass media, not all studies agree that consuming mass media is influential on political knowledge and behaviors (Brinkman, 1968;

Delli Carpini \& Keeter, 1996; Chaffee et al. 1970; Baumgartner, 2008; Hoffman \& Young, 2011; De Vreese \& Boomgaarden, 2006; Liu et al. 2013). 
Generally, scholars show a positive effect of political media consumption on increasing political participation and knowledge (De Vreese \& Boomgaarden, 2006); however, not all media consumption types have the same effect (Robinson \& Davis, 1990; Delli Carpini \& Keeter, 1996; Eveland \& Scheufele, 2000; Liu et al. 2013). These studies overwhelmingly show that newspaper use has a larger positive effect on political participation and knowledge than television use (Liu et al. 2013; Eveland \& Scheufele, 2000), and some even demonstrate a negative effect of television news consumption on political knowledge (Delli Carpini \& Keeter, 1996). The ineffectiveness of television could be attributed its tendency to skew towards lower educated people who may have difficulty understanding the information (Neuman et al. 1992), yet structural tendencies of television, such as its tendency to loosely connect facts and events, could also explain this inability (Graber, 1994). This influential difference between television and newspaper can also be attributed to the differences in political content which they convey. Newspapers have been shown to have high levels of political content while television has less (De Vreese \& Boomgaarden, 2006); subsequently, consuming news media with low levels of political content demonstrates little to no positive effects on political knowledge (De Vreese \& Boomgaarden, 2006). Political news media across these two types of media and others can use humor to influence viewers, which is strongly supported by many theories.

\section{Theories and Demand of Political Humor}

Political humor and satire are common techniques used today in modern day politics and throughout history (Baumgartner \& Morris, 2012) because they are impactful ways to communicate messages to people (Brinkman, 1968; Berg \& Lippman, 2001). The most frequently used theoretical basis to explain this persuasive power is the Elaboration Likelihood Model (ELM) first proposed by Cacioppo et al. (1986). 
The ELM states that there are two paths of persuasion: the central route and the peripheral route. The central route is the deliberate and thoughtful consideration of how solid an argument is based on the information received. In contrast, the peripheral route determines persuasiveness by a person's association with cues which are outside of the logical coherence of the message. Each route is used at different times and for different arguments, and personality factors, such as need for cognition, can determine the route (Haugtvedt \& Petty, 1992).

People use the central route to process persuasion when they are motivated and able to think about arguments, and they use the peripheral route when there is no motivation nor ability to evaluate an argument. Attitudes formed via the central route are more impactful and lasting than those formed via the peripheral route; however, the peripheral route has more potential for persuasion (Petty \& Cacioppo, 1996). Political humor is said to be processed along the peripheral route, which makes the receiver less critical of the message and increases the likelihood of the receiver being persuaded by it (Baumgartner \& Morris, 2008). Many scholars utilize ELM as a theoretical base for their research into the effects of political humor (Baumgartner, 2007; LaMarre et al. 2014), and there appears to be a supply-side orientation to creating political humor. Essentially, political news media utilize humor to create a larger impact on viewers which in turn increases the power of these media. Although this seems to be a clear reason for news media to use political humor, receivers of such messages also have reasoning to consume it.

According to the Uses and Gratifications Theory (McQuail, 1994), political humor consumption fulfills needs and desires such as diversion, learning topics to discuss within personal relationships, reinforcing personal values, and becoming informed (Lewis, 2008; Young, 2013). It creates an entertaining and educational path through which citizens can learn 
about political news first hand or liven up the day-to-day news they have already received, both of which create a demand by consumers for political humor news programming. Viewing both the ELM and Uses and Gratifications theories together, the demand and supply of political humor should be quite high given its influential power and ability to satisfy its viewers' many needs. Using these theories, scholars have examined the role and impact of political humor news on viewers and society.

\section{Effects of Political Humor}

The field of political humor studies has grown much during the past century, and resultant works have shown the many diverse effects it has on consumers. In one of the earliest works on the effects of political humor, Brinkman (1968) found that editorials with political cartoons showed some power to affect political opinions of readers, but it was the editorials' content that held more influence than the cartoons themselves. Although this work showed only slight promise for the power of humor in politics, later works would find more support. Warner (2004) found that television parody inspires thought and curiosity to question social situations hence increasing the likelihood of being politically knowledgeable. Satirical news, a unique form of political humor news, has also shown a positive effect on viewers' knowledge of current political events (Binford, 2015). However, studies have shown that viewers of "soft-news" political humor shows have inflated perceptions of their own political knowledge (Hollander, 1995). In addition to its effects on political knowledge, political participation can also be affected by the consumption of political humor.

Most studies show that political participation increases when people view more news media with political humor (Lee \& Kwak, 2014; Becker, 2013; Baumgartner, 2008; Cao \& Brewer, 2008). Baumgartner (2008) found that viewing political humor online showed a 
positive impact on future political participation, and Lee and Kwak (2014) demonstrated that consistently viewing sarcastic political media increased people's political participation. Specific political activities such as attending campaign events and joining political organizations also increase with political humor consumption (Cao \& Brewer, 2008). Even though political humor has generally been shown to increase political knowledge and participation, one of its biggest effects is on opinions of the political system at large.

One of the most salient effects of political humor is to increase negative attitudes towards politics and the news media, hence creating a cynicism towards the entire political sphere (Lee \& Kwak, 2014; Baumgartner \& Morris, 2006; Holbert et al. 2007). These negative emotions can change the way in which people participate and interact with politics (Lee \& Kwak, 2014), and the view of one's political efficacy can mediate the interaction between political satire consumption and political participation (Hoffman \& Young, 2011; Hoffman \& Thomson, 2009). Also, political humor which is critical of certain policies and politicians can change viewers' opinions about said topics (Baumgartner \& Morris, 2008). These studies seem to add to the overall importance of political humor on individuals' multiple political characteristics; these multiple effects of political humor have only begun to be studied in relation to TCR.

\section{Theoretical Importance and Effects of $T C R$}

As stated before, $T C R$ received much attention from the American public because of its appearance in many parts of the American political sphere. In terms of its overall importance, scholars hold mixed reviews on the power of the show and its ability to impact politics. TCR used its nightly platform to call attention to many specific political issues, social injustices, and political scandals of the time (Jones et al. 2012). Many scholars state that $T C R$ held a critical role in democratic society, and ironically, it and other fake news shows like The Daily Show 
were sometimes seen to be more credible than real news (Anderson \& Kincaid, 2013). TCR also provided a debate stage where opinions that were not held by the mainstream media could be discussed (Meddaugh, 2010). As shown through Herman and Chomsky’s Propaganda Model (2002), this role is very important for establishing true opinions not entirely created by elites. In light of this role, TCR has been shown to be a better critique of mass media and society than other fake news programs (Anderson \& Kincaid, 2013).

Anderson and Kincaid (2013) reviewed both The Daily Show and TCR through the Propaganda Model to see how much each show would diverge from and critique mainstream narratives. Surprisingly, $T C R$ was found to challenge the status quo of politics more than The Daily Show while also following the mainstream narrative. This is not to say that $T C R$ had the ability to influence all of its viewers through its divergent critiques in the same way or power. In fact, political ideology had a large impact on how people perceived and interpreted the show's content and messaging.

Although $T C R$ was clearly a satire of conservative talk show programs, not everyone was able to see behind the satire to his implicit messages. As discussed before, liberals saw the implicit messages behind Colbert's satire and did not believe he was serious when stating his opinions, but conservatives were likely to report Colbert as joking but really meaning what he stated (LaMarre et al. 2009). Others studies agree, stating that although he was implicitly critiquing conservative talking points, $T C R$ actually increased positive views of Republican policies by both Democratic and Republican viewers (Baumgartner \& Morris, 2008). Colbert's satire might not have been effective in changing viewer attitudes towards his "true" beliefs, but conservatives and liberals had no doubt that his show was funny and entertaining independent of their political leanings (Lamarre et al. 2009). Because TCR was most likely processed through 
the peripheral route as predicted by the ELM (Baumgartner \& Morris, 2008), there was much potential for him to influence the political attitudes, participation, and knowledge of his viewer base; however, not many studies have examined these potential impacts of the show.

While minimal quantitative studies have been conducted with $T C R$ as a separate independent variable, there are some studies that do support positive effects of the show on political knowledge, participation, and attitudes as predicted by the ELM (Fowler, 2008; Binford, 2015; Baumgartner \& Morris, 2008; Hoffman \& Young, 2011; LaMarre, 2013; Peterson, 2012). For example, the program demonstrated a stark effect towards increasing support for guests who appeared on the show. The "Colbert Bump" is referred to as the dramatic increase in campaign donations that both Democratic and Republican politicians receive after appearing on his show (Fowler, 2008). Although not a clear causal relationship of the show's effects on political knowledge and participation, $T C R$ viewers were clearly paying attention to Colbert's guests and remembered their names long enough to donate money to them. This increased political engagement effect has been supported by other studies which show TCR raising viewers' political knowledge (Hardy et al. 2014; Binford, 2015), lowering viewers' perceptions of their political efficacy (Baumgartner \& Morris, 2008), and increasing their political participation (Hoffman \& Young, 2011; Peterson, 2012).

\section{Gaps in Research}

There are many gains to be made in political humor literature in general and specifically towards literature about TCR. One thing that is difficult to navigate is the differences between political humor, satire, entertainment talk shows, fake news, and real news. Better distinctions and stricter definitions should be made in future scholarly discussions to clear up confusion among these terms. For this research, political satire will be treated as a subcategory of political 
humor yet completely distinct from it. Political satire shall refer to humor derived from implicit political messaging hidden behind direct explicit messages. For reference points, TCR will be viewed in this research as purely a satirical show due to Colbert's use of conservative messages to state his liberal views, while shows like The Daily Show and Last Week Tonight will be viewed as political humor due to their explicit use of liberal messages to convey liberal views.

Another gap in the literature, as discussed before, is that not much research has been conducted on the individual impact that $T C R$ had on viewers' political characteristics such as political knowledge and political participation. Studies typically combine TCR and The Daily Show into a single political satire variable instead of treating them as separate sources of news (Peterson, 2012; Binford, 2015; Hoffman \& Young, 2011; Brändlin, 2013), and much more research has been conducted on individual effects of The Daily Show's on these outcomes (Lee \& Kwak, 2014; Cao \& Brewer, 2008; Hoffman \& Thomson, 2009). Many times, TCR is left out of these quantitative studies. Studies about $T C R$ tend to be qualitative discussions about its differences with other shows and its significance towards media and democracy (Jones et al. 2012; Meddaugh, 2010); however, these studies fail to explicitly and directly connect $T C R$ to empirical and characteristic changes in viewers. When these quantitative studies have been done, $T C R$ is rarely the singular main focus.

Although it is a difficult task given the amount of variables influencing individuals' political lives, more quantitative research should be conducted to identify paths of causation between viewing $T C R$ and political knowledge and participation. The lack of studies could be due to the relatively short time the show was running in comparison to other shows and a general understanding that Colbert played second fiddle behind Stewart's earlier time slots and gravitas. Regardless, the show was running for enough time to have multiple impacts on viewers, and if a 
viewing effect is found for $T C R$, this can and should encourage more quantitative research into newer and ongoing political humor shows like Last Week Tonight.

Adding further to the empirical difficulties, there is not much available data which can be used to conduct quantitative analyses on TCR. Few political surveys ask if participants have watched the show, and to the knowledge of this research, there seems to be no panel data which can show clear causation paths. Despite the multiple challenges and current gaps of the political humor and TCR literature, this research will contribute to the current field by using other methods to establish causality, filling some quantitative gaps with unique methodology, and devoting its focus to $T C R$ and its empirical political effects on knowledge and participation. 


\section{CHAPTER III. HYPOTHESES AND METHODOLOGY}

\section{Hypotheses}

How much did TCR influence the political knowledge and participation of its viewers? Based upon the current literature, this study hypothesizes that 1) TCR had a significant and positive effect on viewers' political knowledge. Viewers frequently had exposure to many topics in American and world politics which were effectively and influentially presented according to the ELM model and other TCR literature (Baumgartner \& Morris, 2008; Jones et al. 2012; Binford, 2015). Therefore, watching the show should create an increased knowledge of politics, and this knowledge effect might even be greater than other political news shows. In addition to this knowledge effect, this study also hypothesizes that 2) TCR had a significant and positive effect on viewers' political participation. The show frequently inspired viewers to participate in the political process through multiple channels such as events like The Rally to Restore Sanity and/or Fear and donations to political candidates via the "Colbert Bump". TCR viewers should show increased political participation more than non-viewers because of the influential and inspirational methods used throughout the show's history as supported through previous literature (Lee \& Kwak, 2014), yet this study does not believe the effect will hold across all individuals and political preferences. This leads to the last hypothesis that $\mathbf{3}$ ) political party identification will modify the relationship between watching TCR and political participation with only Democrats showing a significant and positive rise in participation from $T C R$ viewing.

According to the literature, both liberals and conservatives watched the program and found it to be entertaining and educational (Gaines, 2007). The educational aspect of the show should not be affected by the political party identification of the viewer because partisanship should not affect the absorption of news, yet political participation could be affected due to 
individuals' abilities to understand the underlying messages of the show (LaMarre et al. 2009). Although not a perfect correlation, this study will use political identification as a proxy for political ideology with Democrats as liberal and Republicans as conservatives. Democrats could potentially see the show's message as a call to arms because they were able to see the veiled and implicit liberal messages, but it is likely that conservative Republicans were not incited by these calls because they took Colbert by his literal words. To put all the hypotheses of this study together, Democrats should show higher levels of political participation than Republicans from watching the show, but both groups' levels of political knowledge should be equally and positively affected due to no hypothesized moderating effect of partisanship on political knowledge.

To test all three hypotheses, individual level survey data from the 2012 ANES Evaluations of Government and Society Study (henceforth EGSS4) and three Pew Research Center Biennial Media Consumption Surveys (henceforth Pew MCS Year) from 2008 to 2012 will be analyzed. All four surveys are nationally representative with large sample sizes and randomized collection methods. The following table describes each survey through its methods, sample, and relation to the Colbert hypotheses. 
Table 1 - Surveys

\begin{tabular}{|c|c|c|c|c|c|}
\hline Survey & Respondents & $\begin{array}{c}\text { Colbert } \\
\text { viewing } \\
\%\end{array}$ & Sampling & Administered & $\begin{array}{l}\text { Error } \\
(+-\%)\end{array}$ \\
\hline $\begin{array}{c}\text { ANES } \\
2012 \\
\text { EGSS4 }\end{array}$ & 1314 & $9.50 \%$ & $\begin{array}{c}\text { Cross-sectional, telephone- and } \\
\text { address-based representative samples } \\
\text { of the national population of US adult } \\
\text { citizens }\end{array}$ & $\begin{array}{c}\text { Internet, } \\
\text { February } 18-23 \\
2012 \\
\text { Response Rate: } \\
2.5 \%\end{array}$ & $(+-2.8 \%)$ \\
\hline $\begin{array}{l}\text { Pew } \\
\text { MCS } \\
2008\end{array}$ & $\begin{array}{c}\text { Total: } 3615 . \\
\text { Colbert: } 1824\end{array}$ & $29.70 \%$ & $\begin{array}{l}\text { Combination of landline and cellular } \\
\text { random digit dial (RDD) nationally } \\
\text { representative of adults in the } \\
\text { continental United States who have } \\
\text { access to a phone. }\end{array}$ & $\begin{array}{l}\text { Telephone, April } \\
\text { 30-June1 } 2008 . \\
\text { Response Rate: } \\
22 \%\end{array}$ & $(+-1.9 \%)$ \\
\hline $\begin{array}{l}\text { Pew } \\
\text { MCS } \\
2010\end{array}$ & 3006 & $37.80 \%$ & Same as Pew MCS 2008 & $\begin{array}{l}\text { Telephone, June } \\
\text { 8-June } 282010 . \\
\text { Response Rate: } \\
16.9 \%-17.5 \%\end{array}$ & $(+-1.9 \%)$ \\
\hline $\begin{array}{l}\text { Pew } \\
\text { MCS } \\
2012\end{array}$ & 3003 & $35.30 \%$ & Same as Pew MCS 2008 & $\begin{array}{l}\text { Telephone, May } \\
9 \text {-June } 32012 . \\
\text { Response Rate: } \\
6.7 \%-11.2 \%\end{array}$ & $(+-2.1 \%)$ \\
\hline
\end{tabular}

These four surveys will strengthen the analysis in ways that a single survey would not.

Given that TCR ran for almost a decade, it would be hard to establish the effect of the show using only one survey. As discussed before, the best dataset for this analysis would be a panel study that would record $T C R$ viewing and the political characteristics of individuals throughout time; sadly, there are no such publicly available datasets. However, given that the listed surveys span a timeframe of four years during Colbert's show, this study can test whether TCR influenced political engagement throughout the years. If the show has an effect only in one year rather than all, this will indicate that the show only had minimal influence on political engagement, but if it is consistent across the surveys, this strengthens the argument that the effects of TCR were not 
merely passing. Another benefit of using multiple surveys is that it can help determine if political season had any moderating effect on the show's influence to change political engagement.

Perhaps the show only had an effect on individuals during presidential election years (EGSS4, Pew MCS 2008, Pew MCS 2012) instead of congressional election years (Pew MCS 2010) when viewers might be more inclined to watch political news during these higher election turnout years (FairVote, 2016). Having this variability will be able to potentially identify a difference in effect based on the political season.

All the surveys were administered during national election years, but they were given at different times before each election. Perhaps Colbert's show only had an effect when the election season got closer. If the Pew datasets administered six months before elections, instead of nine months like the EGSS4, show an effect, this can show how political season could be a moderating factor. The different political times in these datasets along with how $T C R$ viewing is measured will help establish the effects of $T C R$ viewing. Each dataset measures the independent and dependent variables slightly differently, and this can provide strength behind the analyses of each variable. The multiple datasets also provide this study with the ability to measure the dependent variables in similar but varied ways.

\section{Dependent Variables}

The first dependent variable of this study is political knowledge. In the EGSS4 survey, there are four questions which shall be combined into a count variable of political knowledge. In the Pew MCS surveys, political knowledge is a three-point scale in the 2008 survey and a fourpoint scale in the 2010 and 2012 surveys. Each correctly answered political question in each dataset will be attributed one point towards the political knowledge variable for each dataset. As 
the number increases from zero to its maximum of three or four depending on the dataset, the political knowledge score of the participant will show increased knowledge about politics ${ }^{2}$. Table 2 shows the distribution of respondents' correct answers to the political knowledge questions across the surveys.

Table 2 - Political Knowledge Scores

\begin{tabular}{|c|c|c|c|c|c|c|c|}
\hline & \multicolumn{5}{|c|}{ Number of Correct Answers } & \multirow{2}{*}{$\begin{array}{c}\text { Average } \\
\text { Score }\end{array}$} & \multirow{2}{*}{$\begin{array}{c}\text { Total } \\
\text { Frequency }\end{array}$} \\
\hline Survey & 0 & 1 & 2 & 3 & 4 & & \\
\hline Pew MCS2008 & $27.4 \%$ & $27.1 \%$ & $23.0 \%$ & $22.5 \%$ & N/A & 1.41 & 3615 \\
\hline Pew MCS2010 & $13.0 \%$ & $23.0 \%$ & $26.1 \%$ & $21.3 \%$ & $16.7 \%$ & 2.06 & 3006 \\
\hline Pew MCS2012 & $13.0 \%$ & $21.4 \%$ & $22.3 \%$ & $25.3 \%$ & $17.9 \%$ & 2.14 & 3003 \\
\hline EGSS4 & $12.0 \%$ & $16.4 \%$ & $23.0 \%$ & $27.6 \%$ & $21.2 \%$ & 2.30 & 1314 \\
\hline
\end{tabular}

The second dependent variable of this study is political participation. As discussed before, political participation is a key factor in democratic societies because democracy is supported by an engaged citizenry. If viewing $T C R$ had an effect on political participation, these results could reveal how democratic societies can engage citizens in the political process through political humor in the media. On the EGSS4, political participation will be a count variable from zero to five with higher levels indicating more political participation. As each question has different response types, values of "one" and "zero" will be given to responses as shown in the appendix. In addition to this aggregated political participation variable, each form of political participation ranging from minimal participation such as discussing politics with family and friends to more extensive participation including donating to political campaigns will be

\footnotetext{
${ }^{2}$ Questions and their answers are presented in the appendix.
} 
measured independently. This will allow a more nuanced view into the effect of $T C R$ on certain forms of political participation which could have required greater or lesser effort and resources. In the Pew MCS surveys, measuring political participation is extremely limited by their question sets; only one question on each MCS survey asks about being registered to vote. This is not a compelling enough form of political participation to be worth the analysis. Given that the EGSS4 has varied forms of political participation which accurately measure overall political participation more than voter registration, this study will only use the EGSS4 to analyze political participation. As with the political knowledge variable, it is impossible for this variable to completely summarize the entire political participation of individuals; however, both the political knowledge and participation variables will be proxies for individuals' complete political engagement in both aspects.

Table 3 - Political Participation Scores

\begin{tabular}{|c|c|c|c|c|c|c|c|c|}
\hline \multirow[b]{2}{*}{ Survey: EGSS4 } & \multicolumn{6}{|c|}{ Number of Experienced Political Participation Events } & \multirow[b]{2}{*}{$\begin{array}{c}\text { Average } \\
\text { Score }\end{array}$} & \multirow[b]{2}{*}{$\begin{array}{c}\text { Total } \\
\text { Frequency }\end{array}$} \\
\hline & $\begin{array}{c}0 \\
\text { (No) }\end{array}$ & $\begin{array}{c}1 \\
\text { (Yes) }\end{array}$ & 2 & 3 & 4 & 5 & & \\
\hline Total Score & $8.8 \%$ & $30.7 \%$ & $72.8 \%$ & $19.1 \%$ & $6.9 \%$ & $1.1 \%$ & 1.97 & 1314 \\
\hline (Presidential Vote) & $19.6 \%$ & $80.4 \%$ & & & & & & 1314 \\
\hline (Primary Vote) & $83.3 \%$ & $16.7 \%$ & & & & & & 1314 \\
\hline (Discuss Politics) & $25.0 \%$ & $75.0 \%$ & & & & & & 1314 \\
\hline $\begin{array}{l}\text { (Campaign Button / } \\
\text { Sticker) }\end{array}$ & $88.7 \%$ & $11.3 \%$ & & & & & & 1314 \\
\hline $\begin{array}{l}\text { (Donate to } \\
\text { Campaign) }\end{array}$ & $86.5 \%$ & $13.5 \%$ & & & & & & 1314 \\
\hline
\end{tabular}

It can be generalized that individuals who answer affirmatively and correctly to these questions will most likely participate more in and know more about politics overall. In addition, each of the questions is weighted equally towards the final variables of both aggregated political 
participation and knowledge dependent variables. One could argue that giving money to a political candidate constitutes more engaged political participation than voting or that knowing the Supreme Court Justice is more knowledgeable than knowing who controls Congress; however, this study will assume that each question is equally weighted in its importance for each dependent variable. The variances in these two dependent variables of political knowledge and participation will be explained by one main independent variable of "watching $T C R$ " and a list of control variables.

\section{Independent Variable}

"Watching TCR" will be the main independent variable in all the four datasets. In the EGSS4 dataset, it is operationalized as a dummy variable coded "zero" for non-monthly viewers and "one" for monthly viewers. This measure captures relatively frequent viewers of $T C R$, but it admittedly leaves out such factors as viewing frequency of watching the show more than once per month and level of interest in the program. To account for these factors, the Pew MCS surveys measure TCR viewing by frequencies of "Never", "Hardly Ever", "Sometimes", and "Regularly".

Table 4 - Watching TCR

\begin{tabular}{|c|c|c|c|c|c|}
\hline & \multicolumn{2}{|c|}{$\begin{array}{c}\text { Never } \\
\text { (< Once a Month) }\end{array}$} & $\begin{array}{c}\text { Hardly Ever/Sometimes/Regularly } \\
\text { (> Once a Month) }\end{array}$ & Total Frequency \\
\hline Surveys & $\#$ & $\%$ & $\#$ & $\%$ & $\#$ \\
\hline Pew MCS2008 & 1282 & 70.3 & 542 & $29.7 \%$ & 1824 \\
\hline Pew MCS2010 & 1890 & 63.2 & 1102 & $36.8 \%$ & 2992 \\
\hline Pew MCS2012 & 1905 & 64.7 & 1041 & $35.3 \%$ & 2946 \\
\hline (EGSS4 2012) & 1185 & 91.4 & 112 & 8.6 & 1297 \\
\hline
\end{tabular}


Table 5 - Frequency of Watching

\begin{tabular}{|c|c|c|c|c|c|c|c|c|c|}
\hline & \multicolumn{2}{|c|}{ Never } & \multicolumn{2}{c|}{ Hardly Ever } & \multicolumn{2}{c|}{ Sometimes } & \multicolumn{2}{c|}{ Regularly } & \multirow{2}{*}{ Total Frequency } \\
\hline Surveys & $\#$ & $\%$ & $\#$ & $\%$ & $\#$ & $\%$ & $\#$ & $\%$ & $\#$ \\
\hline MCS2008 & 1282 & 70.3 & 186 & 10.2 & 254 & 13.9 & 102 & 5.6 & 1824 \\
\hline MCS2010 & 1890 & 63.2 & 412 & 13.8 & 539 & 18 & 151 & 5.1 & 2992 \\
\hline MCS2012 & 1905 & 64.7 & 392 & 13.3 & 513 & 17.4 & 136 & 4.6 & 2946 \\
\hline
\end{tabular}

At first glance, one large difference between the EGSS4 and Pew MCS surveys is their response rate for TCR viewing. Only $8.6 \%$ in the EGSS4 said they watched the show "at least once a month" compared to $35.3 \%$ who said they watch the show "sometimes" or "regularly" in the same year as the Pew MCS2012 survey; however, this could be due simply to the fact that the Pew MCS surveys do not give a definite amount frequency to classify each category. Upon viewing these $8.6 \%$ EGSS4 "at least once a month" viewers in terms of the Pew MCS "regular" and "sometimes" viewers in the Table 5, one can see that perhaps the Pew MCS respondents who indicated "sometimes" watched the show a little less than once a month and "regularly" did so more than once a month. Although only a rough estimate, it does give a general sense of how to compare the variables from both survey methods ${ }^{3}$.

Measuring $T C R$ viewing in both dichotomous and more varied frequency terms will not only support if merely watching the show had an effect on political knowledge and participation; it will also test if intensity and engagement with the show was necessary to have an effect. In comparison to non-viewers, viewers should show higher rates of political knowledge and participation due to the powerful influence, ability to appeal to both conservatives and liberals,

\footnotetext{
${ }^{3}$ For comparison with the other news programs in this study, the average "more than never" viewing frequencies across the Pew surveys of the other television programs are as follows: $C B S / A B C / N B C-70 \%, C N N / M S N B C / F O X-$ 80\%, The Daily Show - 37\%, and O'Reilly Factor - 43.3\%. As shown, each was more widely viewed than TCR.
} 
and the educational programming of $T C R$. To better isolate the effects of watching the program in relation to other factors, a list of control variables which can also affect participation and knowledge will be included in the statistical models.

\section{Control Variables}

Demographic characteristics such as age, gender, race, political party identification, partisan strength, level of education, and income level have all been shown to affect political knowledge and participation (Kenski \& Stroud, 2006). Intuitively, people who watch more news shows and read more newspapers have increased levels of political knowledge and participation (De Vreese \& Boomgaarden, 2006; Liu et al. 2013). Therefore, these controls ${ }^{4}$ will be included in the models to better test the causality between watching TCR and political knowledge and participation. Also, because previous political humor literature has been dominated by discussions of The Daily Show in relation to TCR, The Daily Show has been included as a control in the models. When The Daily Show is not able to be used as a control in the Pew MCS 2008 due to the questions about both shows being asked on non-overlapping forms, The O'Reilly Factor is used as a control in addition to separate models using only The Daily Show in order to compare the relative strength between the shows. Using The Daily Show will also allow this study to measure the potential differences between satire and humor in political media. As discussed before, both styles of humor can be quite influential towards their intended audiences, but satire has been shown to have a potential different effect based upon the message processed by the recipient (Baumgartner \& Morris, 2008). Using The Daily Show as a measure of humor and TCR as one of satire, one can see which method of political humor might be more influential and dominant at changing viewers' political characteristics.

\footnotetext{
${ }^{4}$ Coding of control variables for each survey can be found in the appendix.
} 
Using these control variables along with the different political times, measures of variables, and different years of these surveys will help paint a more conclusive and statistically sound picture of the effects of $T C R$ on political knowledge and participation.

\section{Methodology}

Because both dependent variables of this study are at interval levels, small in number size, and can be seen as increasing numbers of events occurring ${ }^{5}$, Poisson Count Model regressions using two-tailed tests and $95 \%$ confidence intervals will be conducted to test the effect of the independent variable (watching $T C R$ ) on two dependent variables (political knowledge and political participation). When political participation is separated into its different forms, logit regression models will be used due to the binary nature (yes/no) of the participation types. In addition to the main independent variable, a list of control variables will be included in the analyses. This statistical control methodology contributes to the small literature previously conducted on TCR and political humor because of the current lack of non-experimental methods and nation-wide surveys in the literature. Also to the knowledge of the author, it will be the first study to use the EGSS4 survey to study the effects of TCR on political knowledge and participation. In addition to this contribution to the literature, this study will add to limited quantitative methods previously used to study $T C R$. It aims to be broad scope of the show and its effects on viewers, and it hopes to do justice to the impact it left on American politics.

\footnotetext{
5 This study recognizes that OLS can also be used, but Poisson regression is more appropriate for this study because of the small values and positive nature of the dependent variables. All models were also ran using OLS to see any significant differences in the regression outcomes. Using OLS increases the number of statistically significant variables in some of the models, but it does not change the direction of their effects. The overall analysis does not change by using OLS. When significant differences between OLS and Poisson occur, they are noted in footnotes.
} 


\section{CHAPTER IV. POLITICAL KNOWLEDGE RESULTS AND DISCUSSION}

The first hypothesis of this study is that watching $T C R$ would positively affect viewers' levels of political knowledge. This study finds strong evidence to support this hypothesis. TCR did in fact make viewers more knowledgeable about politics, with the educational effect of the show perhaps even stronger than national news and political humor programs. Table 6 below shows the results of the multiple models conducted, each of which presents a more complete picture of how $T C R$ held this educative power over time and even when held constant by other traditional and comparable political news sources. For the three surveys which show TCR having a significant effect on political knowledge, Figure 1 shows how viewing TCR increased viewers' political knowledge scores. Although the show presents a strong effect across the many models and time periods, several points must be illuminated to understand how and why TCR was effective. 


\begin{tabular}{|c|c|}
\hline 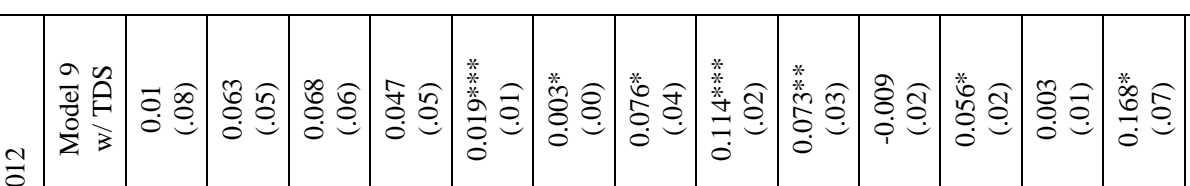 & $\frac{7}{80}=$ \\
\hline 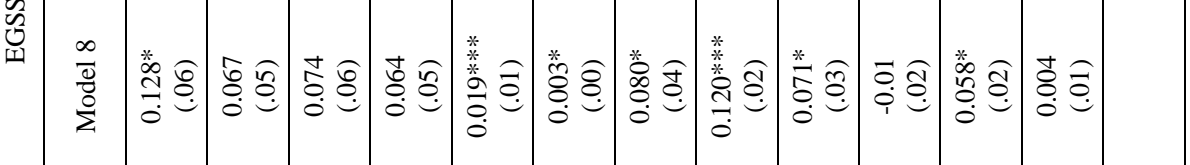 & \\
\hline 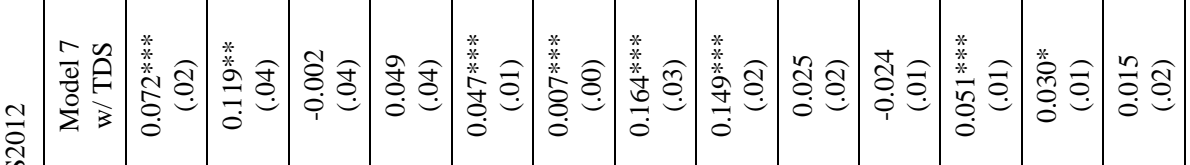 & \\
\hline 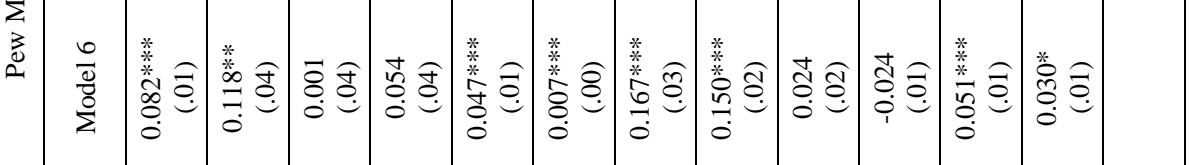 & \\
\hline 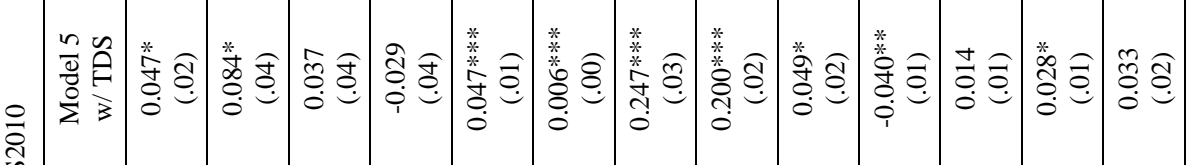 & \\
\hline 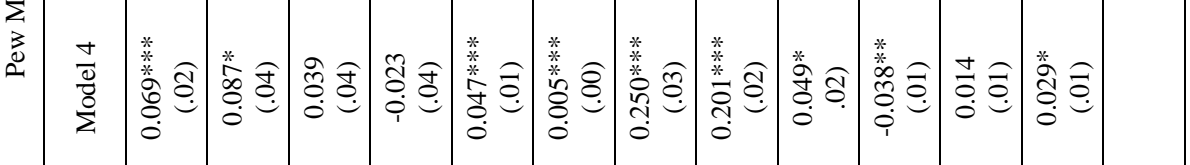 & \\
\hline 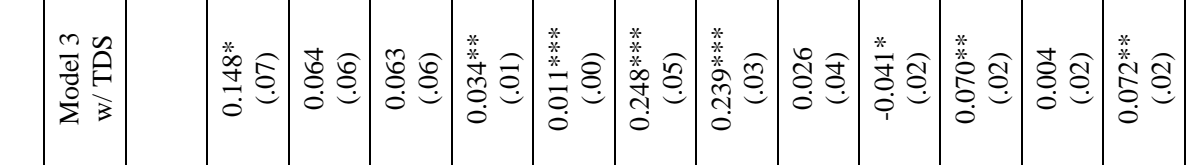 & \\
\hline 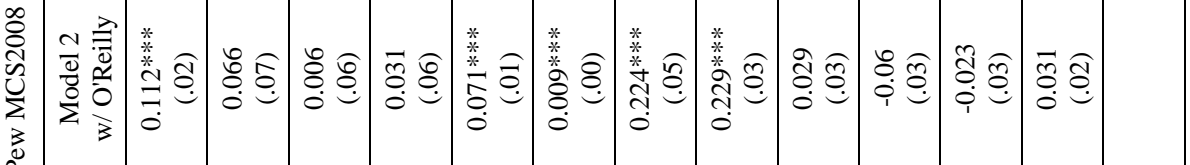 & \\
\hline 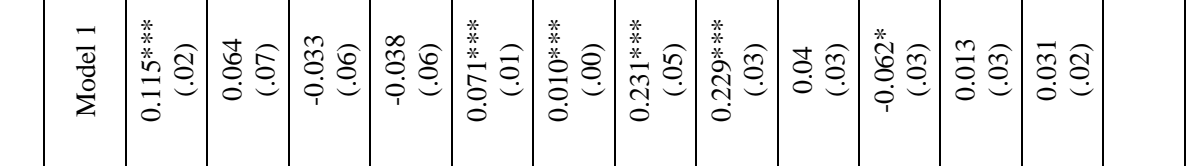 & \\
\hline ร & \\
\hline
\end{tabular}


Figure 1 - A Rise in Truthiness

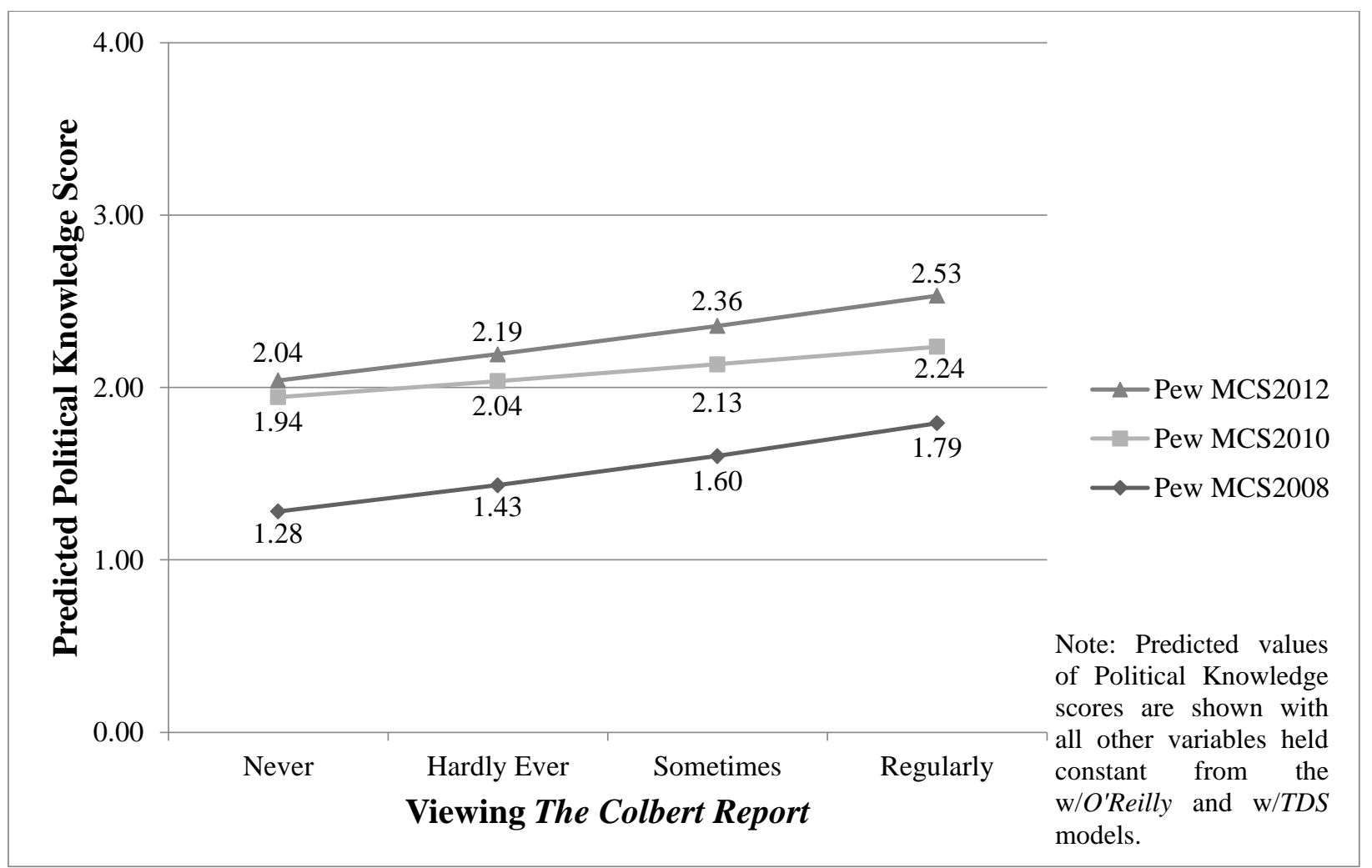

Watching TCR holds a significant and positive effect on political knowledge across all time periods from 2008 to 2012. To put some color to this, someone who never watched TCR, while holding all other variables constant, had a $13 \%$ chance of not getting a single answer correct on the Pew MCS 2012; however, regularly watching TCR lowered that same no correct answer probability by 5\%. In the Pew MCS 2010, TCR lowered the no correct answer probability by $4 \%$, and although it is not held constant by The Daily Show in 2008, it lowered that same probability by $11 \%$. There seem to be no demonstrably different variations in the increases in political knowledge between the different viewing frequencies as demonstrated in Figure 1. For example in the Pew MCS 2010 Model 5, jumping from "never" watching to "hardly ever" watching increased the political knowledge score by about .1 points, essentially the 
same increase as jumping from "sometimes" to "regularly" watching. This suggests that there was no magical point where only certain minimum frequency and above $T C R$ viewers would benefit their political knowledge from watching the program; rather, it seems the relationship between viewing TCR and political knowledge was constant instead of increasing in intensity.

This ascribes a certain long lasting and consistent educational power to the show as predicted. This does not come as a surprise given Colbert's viewership remained relatively constant over the years, indicating a continually interested viewership, and that he maintained his focus on political news and current events over the course of his show. In surprising opposition of previous literature results, which claimed TCR as less impactful and important than The Daily Show, TCR seems to hold a stronger effect on political knowledge across time than The Daily Show ${ }^{6}$. This is shown by comparing the standard models and the w/TDS (The Daily Show) models in the latter two Pew MCS surveys in which TCR eliminates the statistical significance of The Daily Show. Following are some explanations which can be attributed to this finding.

First, political satire could be more effective at educating viewers than direct messaging types of political humor. This comparative study of humor has not been the focus of much research, but it is crucial when determining the effectiveness of messaging. Buijzen and Valkenberg (2004) expressed a need to differentiate between different humor types when analyzing their effectiveness, yet as discussed before, many studies have lumped these different humoristic categories together, eliminating the nuances that can be found between different forms. Even within its own category of humor, different forms of satire can have varied effects on individuals. Holbert et al. (2011) found that different satire forms were more effective at persuasion for different groups than others; however, what the scholars did not consider is their

\footnotetext{
${ }^{6}$ When OLS is used, The Daily Show does gain statistical significance in the Pew MCS 2010; however, TCR still holds more statistical significance across the majority of models where both variables are included.
} 
comparative effects on educating viewers. Specifically for $T C R$, Baumgartner and Morris (2008) found that because of the potential overpowering of the explicit conservative message over the implicit liberal one, the effects of Colbert's satirical program on persuading individuals were perhaps short lived. However, the consistency of the three Pew surveys suggests that TCR in fact did have lasting effects on its viewership, even potentially more so than The Daily Show. To better determine if political satire is more impactful than more direct political humor types, more experimental studies should be conducted using political satire and other humor types to convey the same message. Additionally, research should include check ins through panel studies to see the effectiveness of different humor types at educating in the long run. This leads to the next potential reason of the educational power of TCR: election season.

Second, TCR might have shown a larger effect than The Daily Show on political knowledge during times closer to national election cycles. Observing both EGSS4 models, The Daily Show completely eliminates the statistical significance and reduces the $T C R$ coefficient to almost zero. While this effect is what previous literature has inferred, this decreased significance may also be explained by the moderating factor of the election cycle. It is a point that Baumgartner and Morris (2008) make by stating, "[although the short-lived effects of TCR] are less than significant, it should be remembered that short-term effects can often have a powerful influence in politics, for example, in election campaigns (Baumgartner \& Morris, 2008, p. 635).” When viewing the results through this election cycle lens, the pieces seem to come together.

Each Pew MCS survey was administered during national elections years between late April and June, placing these surveys two to four months closer to the elections in November than the EGSS4 administered in February of the election year 2012. This also places these surveys in political contexts closer to the latter primaries which ultimately seal the nominations. 
Overall increased political attention around the party primaries and the national elections could have increased Colbert's viewership and made it focus more on the political news segments of the show in order to learn from them. When less attention was gathered around politics in the earlier parts of the year, people could have relied more on The Daily Show for their humor and political education fixes hence explaining the significance of this show in the EGSS4.

When considering $T C R$ 's effectiveness during congressional versus presidential elections, there seems to be no difference given that all the Pew surveys show statistical significance of $T C R$ in both election cycle types, but future research should be conducted on how timing and political context of news shows can have an impact on their effectiveness. Lastly, TCR could show more statistical significance than The Daily Show due to the segmentation of watching frequency.

Had this study only operationalized $T C R$ viewing as a dichotomous yes/no factor, as does the EGSS4, the evaluation could have skewed more towards the effectiveness of The Daily Show. By using a more continuous approach to viewing news, which teases out the effects of heavy viewing versus light viewing, the results show that $T C R$ does hold a significant and positive impact, even more so than other news and political humor programs. This indicates that viewers who watched $T C R$ more than other programs benefited their political knowledge levels as their viewing frequency increased, but watching the program only infrequently would not allow strong knowledge gains for individuals.

Although this study hypothesized that individuals, no matter their partisan ideology, would increase their political knowledge from watching $T C R$, it found results indicating that partisanship did influence how TCR educated viewers. Table 7 lists the results of how political knowledge gains from TCR viewing were acknowledged solely by Independents and Democrats. 
The sizeable Republican share of Colbert's viewership, $15 \%$ in the EGSS4 and $21 \%$ in the Pew MCS $2010^{7}$, did not seem to gain political knowledge from watching the program. Independents gained the most in political knowledge from watching TCR as their knowledge gains are seen across all the three Pew MCS surveys, but the effects for Democrats, the highest portion of TCR viewership, did not hold significance across the same surveys ${ }^{8}$. None of the surveys showed any significant knowledge benefit for Republican TCR viewers, and some coefficients for Republicans, although not statistically significant, were negative. Apparently, partisanship had a large factor to play, and those who were least partisan of all benefitted the most. For political knowledge to stick, it appears that TCR's satire needed to hit its target audience.

Although Republicans saw Colbert as being funny and entertaining (Lamarre et al. 2009), it seems entertainment was the full extent to which they benefited from the program. Using the Uses and Gratifications Theory (McQuail, 1994), we can now see that a typical Republican viewer was probably using $T C R$ for its humor and not its ability to inform because of the missing effect on their political knowledge. For Democrats and Independents, we can see that they were probably using TCR for both its humor and informative power. The information probably stuck for Democrats and Independents because they were able to understand the jokes hidden behind the explicit direct messaging and tie that humor to the knowledge. To do this, Colbert would first have to set up the jokes like a teacher might structure a day's lesson.

\footnotetext{
7 This is calculated as being Republican respondents who indicated "sometimes" or "regularly" to watching $T C R$.

${ }^{8}$ When OLS is used, Democrats do show a statistically significant knowledge gain across all the Pew surveys.
} 


\begin{tabular}{|c|c|c|c|c|c|c|c|c|c|c|c|c|c|c|c|c|}
\hline 气̆ & 离 & 莺 & 交京 & 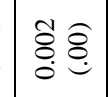 & 言惫 & 善悉 & 惫总 & 音兽 & 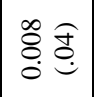 & 总产 & 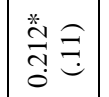 & & $\mid$ & 多 & & \\
\hline 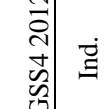 & 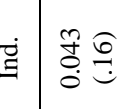 & 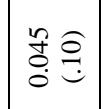 & 尊产 & 总 & 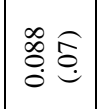 & 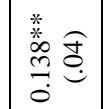 & 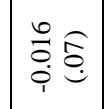 & 总舍 & 鄫要 & 吕产 & 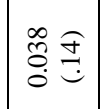 & & శֶ? & 怘 & & 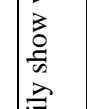 \\
\hline & 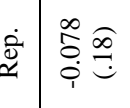 & : & $\mid \begin{array}{ll}0 \\
0 \\
0\end{array}$ & 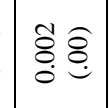 & 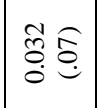 & 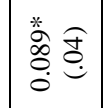 & 酸绨 & 言商 & 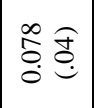 & - $0 \hat{\mathrm{a}}$ & $\frac{D}{0}=$ & & 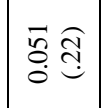 & $\underset{\infty}{\infty}$ & & 噌 \\
\hline & 言 & 曽拿 & 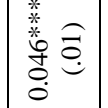 & 裳递 & 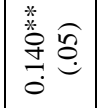 & 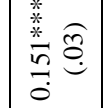 & 客象 & 宅 & 8ृ: & 哥 & 형영 & & 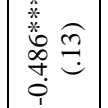 & 串 & & $\begin{array}{l}0 \\
0 \\
0 \\
0 \\
0\end{array}$ \\
\hline & 憘善畄 & : & 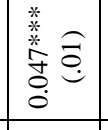 & 恶惫 & 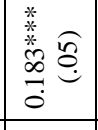 & 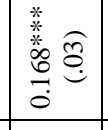 & 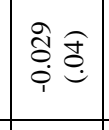 & 产 & 善忽 & 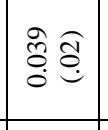 & 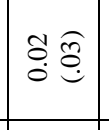 & & 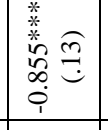 & ద్ & & 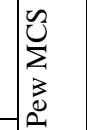 \\
\hline & 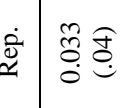 & 旁预 & 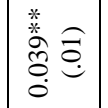 & 䓂总 & 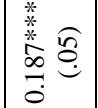 & 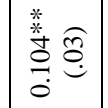 & 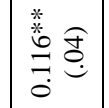 & 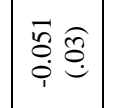 & 善商 & 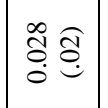 & | & & 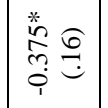 & 象 & ?o & $\mid$ \\
\hline & 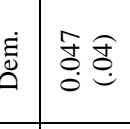 & 8 & 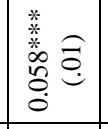 & 善总 & 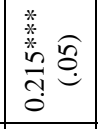 & 恶总 & 吾 & 容舍 & 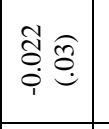 & 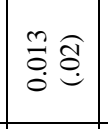 & 总鱼 & & 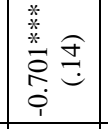 & $\mathscr{\infty}$ & है & \\
\hline & E: & $\stackrel{n}{a}$ & 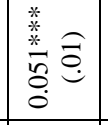 & 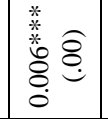 & 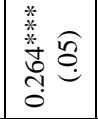 & 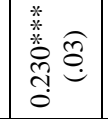 & 染 & 歌 & 종 & 言 & 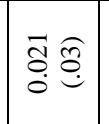 & & 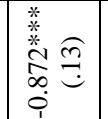 & $\ddot{\infty}$ & $\begin{array}{l}\infty \\
\stackrel{\infty}{0} \\
0\end{array}$ & \\
\hline & 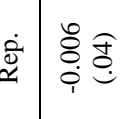 & 商 & 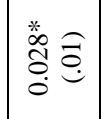 & 善鄫 & 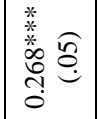 & 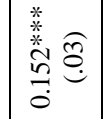 & 兽慙 & 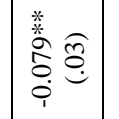 & 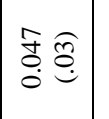 & 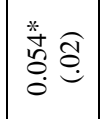 & 要要 & & 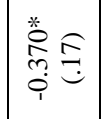 & $\vdots$ & 宮 & \\
\hline 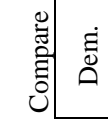 & 离 & $\overbrace{0}^{\infty} \widehat{\theta}$ & 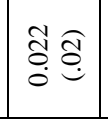 & 眻总 & 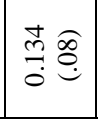 & 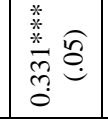 & 童 & 兽鱼 & 嘉总 & 嘉季 & 善悉恶 & & 竟希 & 多 & 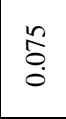 & \\
\hline & & $\frac{n}{8} \stackrel{\frac{m}{0}}{g}$ & 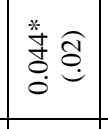 & 嘭总 & 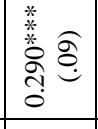 & 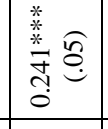 & 萨㣽 & 总車 & 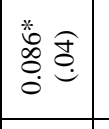 & 管艒 & 謇要要 & & 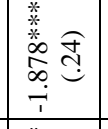 & $\underset{f}{\not}$ & $\frac{\mathrm{t}}{0}$ & \\
\hline & & 웡 & 范 & 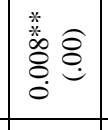 & 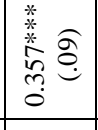 & 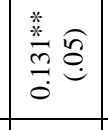 & 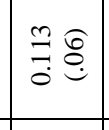 & 急商 & 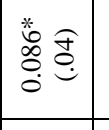 & 讋悉 & 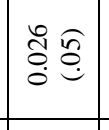 & & 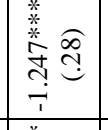 & $q$ & : & \\
\hline & 言 & 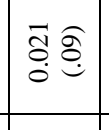 & 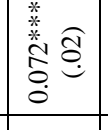 & 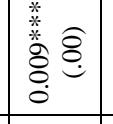 & 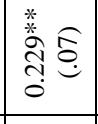 & 維 & 象 & 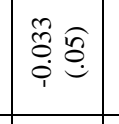 & 总畄 & 造看 & & 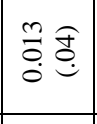 & 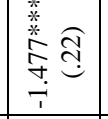 & के & gे & \\
\hline 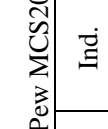 & 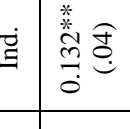 & 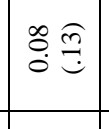 & 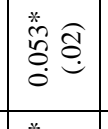 & 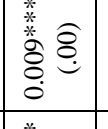 & 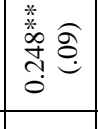 & 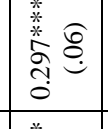 & 吕会 & 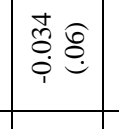 & 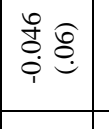 & 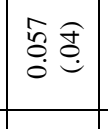 & & $\begin{array}{l}0 \\
0 \\
0\end{array}$ & 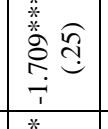 & 9 & $\frac{\mathrm{o}}{\mathrm{o}}$ & \\
\hline & ث: & EE & 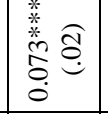 & 善䇏 & 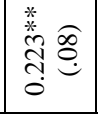 & 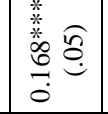 & 象 & 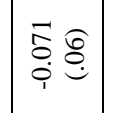 & 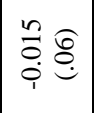 & 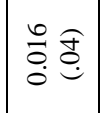 & & 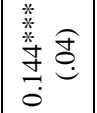 & 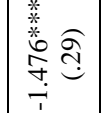 & F & $\vec{\infty}$ & \\
\hline 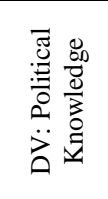 & $\underset{\vDash}{\S}$ & $\frac{0}{\frac{2}{2}}$ & 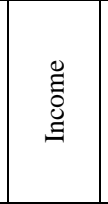 & 喿 & 递 & $\begin{array}{l}\text { 竧 } \\
\text { 离 }\end{array}$ & 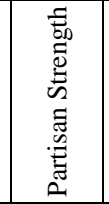 & 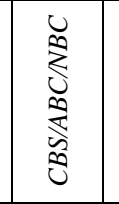 & 总 & 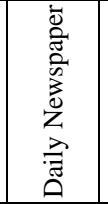 & 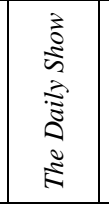 & 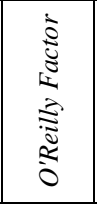 & 言 & z & 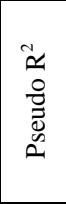 & \\
\hline
\end{tabular}


Bringing in a pedagogical viewpoint, Colbert's style was similar to the way in which some teachers structure lesson plans using a technique called 4MAT (Wilkerson \& White, 1988). 4MAT lesson plans have a specific structure which goes as follows. First, teachers provide the important pieces of information through a lecture or more engaging forms. Second, students practice the information through a relevant exercise with structure from the teacher. After the practice, students are then told to do an application in which they create something personal to themselves in a less structured environment using the new knowledge and their previous knowledge and beliefs of the world. Teachers, including this author, have found this lesson structure to be quite effective in enabling students to retain information (Wilkerson \& White, 1988). Using this lesson planning frame, one can see why Colbert's nightly "politics class" was effective.

For TCR's “4MAT lesson planning", Colbert typically provided the relevant information by using news clips from major news networks. These collections of news clips would be informative syntheses of the news itself and of the national news networks' coverage, a frequent area of which Colbert enjoyed poking fun. Next, to allow his viewers a space to practice this new information, he began to analyze the news using his comedic and overly conservative messaging techniques. This practice in itself could potentially make a person remember the political news well enough because of the humor attached, yet Colbert would provide his viewers a next step to bring in their personal beliefs. In the "application phase" of Colbert's lessons, viewers would take their previous beliefs and knowledge of the world (either Colbert as a liberal satirist or an over-the-top conservative comedian), and apply it to his message. When viewers could use their previous knowledge of Colbert as a liberal satirist, they got the rewards of understanding the implicit message, seeing the satire between the explicit and implicit messages, 
and engaging in a short but sweet laugh. Conservative viewers would take their view of Colbert as a conservative comedian and understand the ridiculousness of the jokes in the direct messages, but they would not be able to grasp the true message Colbert was teaching in this phase of the lesson.

The application phase would sometimes even extend into homework, giving viewers an opportunity to apply knowledge even after the lesson. Through post show events like his superpac commercials and a candidacy for becoming the President of the United States of South Carolina, viewers were able to take lessons into the real world and apply them outside of the “classroom". Viewing his satire through this pedagogical lens, it makes sense why only Independent and Democrat viewers were the only ones to gain political knowledge from Colbert's program.

Republican viewers were only able to engage in the synthesis of information during the "practice" portions of Colbert's lessons; they did not join in the application phase where the greatest gains may have resided. Since Republicans' lessons stopped at the practice, maybe their political knowledge gains did as well. This could also explain why Colbert's program held stronger political knowledge gain effects than The Daily Show. Stewart's lessons mostly only went up to the practice phase, tying the political news with a directly liberal joke. If Stewart would have gone past that point by using more satire and stunts to make the information attached to the message even stickier, The Daily Show could have shown equal effects to those of TCR. To test power of satire as compared to other forms of humor at effective political education, future studies should conduct experiments measuring the short-term and long-term political knowledge gains of different styles of humor and techniques. 
To put all of these implications together, $T C R$ was an effective political educator across time, and it appears that because of the satirical style of his program, he was a more effective political educator than national news organizations and similarly minded political humor shows. The show probably functioned best in this role when viewers were more likely to pay attention to the political context closer to election times. Only viewers who were able to see the liberal implicit messages and fully engage in the synthesis, practice, and application of Colbert's satire could fully make that information stick in their long-term memories. Now that $T C R$ has stopped airing, Democrats and Independents have lost an effective way to become smarter about politics, but other programs do show promise in filling this gap like Last Week Tonight (Hoffman, 2015). Nonetheless, it is this author's opinion that no one will ever instill as much "truthiness" as Colbert did. 


\section{CHAPTER V. POLITICAL PARTICIPATION RESULTS AND DISCUSSION}

Events like The Rally to Restore Sanity and/or Fear and previous literature discussing phenomena like the "Colbert Bump" demonstrate that TCR had some effects on viewers' political participation. This study hypothesized that $T C R$ should have made viewers more likely to participate in politics in general and for specific political participation types, such as voting and donating to political campaigns, because of the show's political nature and potentially large influence on viewers. Based on the motivated reasoning effects of partisanship, this study also hypothesized that this motivation to participate effect would only be experienced by Democrats because they were the only ones who could understand the implicit liberal messaging and calls to arms of TCR. However, negating the hypotheses of this study, the results point to no effect of $T C R$ on political participation for neither political party nor participation type. Statistical models demonstrating these political participation results are shown in Table 8.

$T C R$ shows no statistically significant effect in the main statistical model (Model 1) nor for any political identification group. Characteristics that do show effects towards making individuals more likely to participate in politics are being older, having stronger political views, being more educated, reading the newspaper, and watching cable news such as Fox News. Commercial broadcast networks like $\mathrm{ABC}$ do not seem to hold any effect ${ }^{9}$, but this is not surprising given their focus on programming other than political news. One interesting finding in addition to TCR having no effect was a shared lack of power by The Daily Show.

\footnotetext{
${ }^{9}$ When OLS is used, the $A B C / C B S / N B C$ variable does gain a statistically significant and positive effect for Democrats.
} 
Table 8 - The Null Effects of TCR on Political Participation

\begin{tabular}{|c|c|c|c|c|}
\hline $\begin{array}{l}\text { DV: Political } \\
\text { Participation }\end{array}$ & Model 1 & Republicans & Independents & Democrats \\
\hline$T C R$ & $\begin{array}{c}0.064 \\
(.09)\end{array}$ & $\begin{array}{c}0.104 \\
(.18) \\
\end{array}$ & $\begin{array}{c}0.059 \\
(.18) \\
\end{array}$ & $\begin{array}{c}0.024 \\
(.13)\end{array}$ \\
\hline White & $\begin{array}{c}-0.097 \\
(.05)\end{array}$ & $\begin{array}{c}-0.158 \\
(.12)\end{array}$ & $\begin{array}{c}-0.087 \\
(.11)\end{array}$ & $\begin{array}{c}-0.062 \\
(.07)\end{array}$ \\
\hline Independents & $\begin{array}{c}-0.011 \\
(.06)\end{array}$ & & & \\
\hline Democrats & $\begin{array}{c}0.019 \\
(.05)\end{array}$ & & & \\
\hline Income & $\begin{array}{c}0.002 \\
(.01)\end{array}$ & $\begin{array}{c}-0.017 \\
(.01)\end{array}$ & $\begin{array}{l}0.01 \\
(.01) \\
\end{array}$ & $\begin{array}{c}0.009 \\
(.01) \\
\end{array}$ \\
\hline Age & $\begin{array}{c}0.008 * * * \\
(.00)\end{array}$ & $\begin{array}{c}0.007 * * \\
(.00)\end{array}$ & $\begin{array}{c}0.012 * * * \\
(.00)\end{array}$ & $\begin{array}{c}0.005^{*} \\
(.00)\end{array}$ \\
\hline Male & $\begin{array}{c}0.023 \\
(.04)\end{array}$ & $\begin{array}{c}0.009 \\
(.07) \\
\end{array}$ & $\begin{array}{c}0.003 \\
(.08) \\
\end{array}$ & $\begin{array}{c}0.034 \\
(.07)\end{array}$ \\
\hline Education & $\begin{array}{c}0.133 * * * \\
(.02)\end{array}$ & $\begin{array}{c}0.190 * * * \\
(.04)\end{array}$ & $\begin{array}{c}0.149 * * \\
(.05)\end{array}$ & $\begin{array}{c}0.063 \\
(.04)\end{array}$ \\
\hline Partisan Strength & $\begin{array}{c}0.125^{* * *} * \\
(.03)\end{array}$ & $\begin{array}{c}0.134 * * \\
(.05)\end{array}$ & $\begin{array}{c}0.159 * \\
(.07)\end{array}$ & $\begin{array}{c}0.124^{*} * \\
(.05)\end{array}$ \\
\hline$A B C / C B S / N B C$ & $\begin{array}{c}0.027 \\
(.02)\end{array}$ & $\begin{array}{c}0.008 \\
(.04)\end{array}$ & $\begin{array}{c}0.015 \\
(.04)\end{array}$ & $\begin{array}{c}0.049 \\
(.04)\end{array}$ \\
\hline CNN/MSNBC/FOX & $\begin{array}{c}0.060 * \\
(.03)\end{array}$ & $\begin{array}{c}0.116 * \\
(.05)\end{array}$ & $\begin{array}{c}0.009 \\
(.05)\end{array}$ & $\begin{array}{c}0.055 \\
(.04)\end{array}$ \\
\hline Daily Newspaper & $\begin{array}{c}0.019 * \\
(.01)\end{array}$ & $\begin{array}{c}0.029 * \\
(.01)\end{array}$ & $\begin{array}{c}0.004 \\
(.02)\end{array}$ & $\begin{array}{c}0.018 \\
(.01)\end{array}$ \\
\hline The Daily Show & $\begin{array}{c}0.073 \\
(.08)\end{array}$ & $\begin{array}{c}0.077 \\
(.19)\end{array}$ & $\begin{array}{l}0.14 \\
(.17)\end{array}$ & $\begin{array}{c}0.111 \\
(.12)\end{array}$ \\
\hline Constant & $\begin{array}{c}-0.447 * * \\
(.14)\end{array}$ & $\begin{array}{r}-0.38 \\
(.24) \\
\end{array}$ & $\begin{array}{c}-0.796^{* *} \\
(.25) \\
\end{array}$ & $\begin{array}{c}-0.212 \\
(.20) \\
\end{array}$ \\
\hline $\mathrm{N}$ & 1209 & 385 & 385 & 439 \\
\hline Pseudo $\mathrm{R}^{2}$ & 0.047 & 0.06 & 0.045 & 0.036 \\
\hline \multicolumn{5}{|c|}{$\begin{array}{l}\text { Poisson regression coefficients listed. Significance levels: } *<.05, * *<.01 \text {, } \\
* * *<.001 \text {. Standard errors in parentheses. }\end{array}$} \\
\hline
\end{tabular}

Unlike the results of this study for political knowledge, differences between political humor and political satire cannot be seen in their resulting levels of political participation, and therefore both seem to be equally ineffective. News media types that do have an impact are news broadcast networks and daily newspaper reading. These findings suggest that watching $C N N$ and reading a local newspaper can be impactful media to increase political participation 
among the general public, if that public is Republican ${ }^{10}$. For all political partisan groups, watching TCR does not seem to get them to get off their couch and into the democratic process. This finding, although negating the hypothesis of this study, is not surprising given the fact that most Americans do not like to participate in politics, especially for frequent and time consuming events like local elections (FairVote, 2016). However, what if $T C R$ viewers were incited enough to do low effort political activities that could be done from the comfort of their couches like online donating to campaigns or wearing campaign buttons? Table 9 explores this question, and it appears that no matter the level of effort of each participation type, $T C R$ holds equally impotent on all forms of political participation.

\footnotetext{
${ }^{10}$ When OLS is used, the $C N N / M S N B C / F O X$ and Daily Newspaper variables gain a statistically significant and positive effect for Democrats but not Independents.
} 
Table 9 - The Effects of $T C R$ on Forms of Political Participation

\begin{tabular}{|c|c|c|c|c|c|}
\hline Variable & Presidential vote & Primary Vote & $\begin{array}{c}\text { Campaign } \\
\text { button / sticker }\end{array}$ & $\begin{array}{l}\text { Donate to } \\
\text { Campaign }\end{array}$ & $\begin{array}{l}\text { Discuss } \\
\text { Politics }\end{array}$ \\
\hline$T C R$ & $\begin{array}{c}0.271 \\
(.43) \\
\end{array}$ & $\begin{array}{c}-0.251 \\
(.36) \\
\end{array}$ & $\begin{array}{c}0.599 \\
(.37) \\
\end{array}$ & $\begin{array}{c}-0.076 \\
(.38)\end{array}$ & $\begin{array}{l}0.715 \\
(.47)\end{array}$ \\
\hline White & $\begin{array}{c}-0.214 \\
(.23)\end{array}$ & $\begin{array}{c}-0.801 * * * \\
(.19)\end{array}$ & $\begin{array}{c}-0.143 \\
(.25)\end{array}$ & $\begin{array}{c}-0.588^{*} \\
(.23)\end{array}$ & $\begin{array}{l}0.102 \\
(.19)\end{array}$ \\
\hline Independents & $\begin{array}{l}0.373 \\
(.25)\end{array}$ & $\begin{array}{c}-0.365 \\
(.25) \\
\end{array}$ & $\begin{array}{c}-0.083 \\
(.32)\end{array}$ & $\begin{array}{c}-0.239 \\
(.30)\end{array}$ & $\begin{array}{l}0.052 \\
(.22)\end{array}$ \\
\hline Democrats & $\begin{array}{l}0.394 \\
(.23)\end{array}$ & $\begin{array}{l}0.139 \\
(.20)\end{array}$ & $\begin{array}{c}-0.097 \\
(.23)\end{array}$ & $\begin{array}{l}-0.26 \\
(.23)\end{array}$ & $\begin{array}{l}0.028 \\
(.19)\end{array}$ \\
\hline Income & $\begin{array}{l}0.042 \\
(.02)\end{array}$ & $\begin{array}{c}-0.015 \\
(.02)\end{array}$ & $\begin{array}{l}-0.04 \\
(.03)\end{array}$ & $\begin{array}{c}0.012 \\
(.03)\end{array}$ & $\begin{array}{c}0.011 \\
(.02)\end{array}$ \\
\hline Age & $\begin{array}{c}0.063 * * * \\
(.01)\end{array}$ & $\begin{array}{c}-0.003 \\
(.01)\end{array}$ & $\begin{array}{l}0.011 \\
(.01)\end{array}$ & $\begin{array}{c}0.033 * * * \\
(.01)\end{array}$ & $\begin{array}{c}0.016 * * \\
(.01)\end{array}$ \\
\hline Male & $\begin{array}{c}-0.226 \\
(.18) \\
\end{array}$ & $\begin{array}{l}0.123 \\
(.16)\end{array}$ & $\begin{array}{l}0.167 \\
(.19)\end{array}$ & $\begin{array}{l}0.18 \\
(.18)\end{array}$ & $\begin{array}{r}0.197 \\
(.15) \\
\end{array}$ \\
\hline Education & $\begin{array}{c}0.842 * * * \\
(.11)\end{array}$ & $\begin{array}{l}0.09 \\
(.09)\end{array}$ & $\begin{array}{c}0.266^{*} \\
(.12) \\
\end{array}$ & $\begin{array}{c}0.349 * * \\
(.11)\end{array}$ & $\begin{array}{c}0.527 * * * \\
(.09) \\
\end{array}$ \\
\hline Partisan Strength & $\begin{array}{c}0.715 * * * \\
(.13)\end{array}$ & $\begin{array}{l}0.11 \\
(.11)\end{array}$ & $\begin{array}{c}0.530 * * * \\
(.15)\end{array}$ & $\begin{array}{c}0.440 * * \\
(.14)\end{array}$ & $\begin{array}{c}0.403 * * * \\
(.11)\end{array}$ \\
\hline$A B C / C B S / N B C$ & $\begin{array}{c}0.145 \\
(.10) \\
\end{array}$ & $\begin{array}{c}0.069 \\
(.08) \\
\end{array}$ & $\begin{array}{c}-0.006 \\
(.10)\end{array}$ & $\begin{array}{c}-0.044 \\
(.09) \\
\end{array}$ & $\begin{array}{c}0.231 * * \\
(.09)\end{array}$ \\
\hline CNN/MSNBC/FOX & $\begin{array}{c}-0.132 \\
(.12)\end{array}$ & $\begin{array}{c}0.267 * * \\
(.10)\end{array}$ & $\begin{array}{c}0.139 \\
(.12)\end{array}$ & $\begin{array}{c}0.229 * \\
(.11)\end{array}$ & $\begin{array}{c}0.451 * * * \\
(.11)\end{array}$ \\
\hline Daily Newspaper & $\begin{array}{c}0.021 \\
(.04) \\
\end{array}$ & $\begin{array}{c}0.058 \\
(.03) \\
\end{array}$ & $\begin{array}{c}0.138 * * * \\
(.04)\end{array}$ & $\begin{array}{c}0.130 * * * \\
(.03)\end{array}$ & $\begin{array}{r}0.027 \\
(.03) \\
\end{array}$ \\
\hline The Daily Show & $\begin{array}{l}0.04 \\
(.40)\end{array}$ & $\begin{array}{c}0.077 \\
(.33)\end{array}$ & $\begin{array}{c}0.219 \\
(.36)\end{array}$ & $\begin{array}{c}0.639 \\
(.34)\end{array}$ & $\begin{array}{c}0.628 \\
(.40)\end{array}$ \\
\hline Constant & $\begin{array}{c}-5.575 * * * \\
(.57)\end{array}$ & $\begin{array}{c}-1.551^{* *} \\
(.48)\end{array}$ & $\begin{array}{c}-4.576 * * * \\
(.66)\end{array}$ & $\begin{array}{c}-5.878 * * * \\
(.68)\end{array}$ & $\begin{array}{c}-2.772 * * * \\
(.46)\end{array}$ \\
\hline $\mathrm{N}$ & 1209 & 1209 & 1209 & 1209 & 1209 \\
\hline Pseudo $\mathrm{R}^{2}$ & 0.273 & 0.05 & 0.09 & 0.136 & 0.135 \\
\hline
\end{tabular}

$T C R$ viewing holds no significant effect on any individual form of political participation, even for low involvement types like discussing politics with friends. The Daily Show proved equally ineffective. Media that did hold an effect on some participation types were cable news shows and reading a daily newspaper. No type of media consumption was found to increase the likelihood of voting in a presidential election, yet for primary elections viewing cable news seems to increase the likelihood of primary voting. For arguably the least costly and demanding 
form of political participation, discussing politics, TCR does hold the highest coefficient out of all the media variables, but it does not hold any statistical significance. These results disprove both political participation hypotheses by demonstrating the ineffectiveness of viewing $T C R$ on incentivizing political participation.

The political events of TCR including his Rally to Restore Fear and/or Sanity and the pervasiveness of the "Colbert Bump" appear to be short-term anomalies briefly engaging viewers to join in the political process, and this finding contradicts prior studies claiming positive effects of increased viewing of news with political humor (Lee \& Kwak, 2014; Becker, 2013; Baumgartner, 2008; Cao \& Brewer, 2008). A brief explanation might point to the difficulty of encouraging Americans to participate in the political process which can appear to many as boring and everlasting. One could point to the specific ineffectiveness of political satire out of many humor types in this endeavor, but this would not explain the joint ineffectiveness of political humor as seen also with The Daily Show. Perhaps political humor, including satire, is not effective because it does not overcome the problems of collective action and the difficulty to organize people on a large scale. An approach for future studies would be to investigate attendance at political rallies and protests and how political humor shows can increase attendance for collective action events. The null findings on participation could also be due to the timing of the surveys which perhaps did not provide enough recent political participation opportunities for people to indicate in their responses.

Although the surveys were during presidential elections years and in the early primary cycles, many of the participation questions were based on campaign style events and gestures during the 12 months before the survey. Only a truly fervent political person would donate to a campaign so far ahead of the national elections, and the so called early and late majority adopters 
would probably not wear campaign flair until it were somewhat closer to the November

elections. Since a retrospective study asking for responses on November $9^{\text {th }}$ of the survey year is not feasible, future studies should look at how timing of surveys can affect the relationship between media usage and political participation types. The lack of findings attributable to $T C R$ could also be due to the theoretical model used in this thesis.

This study proposed that being able to see Colbert's implicit liberal messaging would encourage Democrat viewers to increase their participation, and perhaps this is an overly idealistic and simple model. Models before have pointed to mediating effects which can affect the relationship between political humor and political participation (Lee \& Kwak, 2014), and it could be that more complex models are better ways to study this relationship. However, the study done by Lee \& Kwak (2014) showed also a direct relationship between political satire ${ }^{11}$ and political participation. This does not provide an explanation behind the ineffectiveness as shown in this study. Nonetheless, future studies should consider other paths through which political humor types can affect political participation and other political characteristics. Finally, $T C R$ might not have proved effective at changing political participation because it was not focused specifically on doing so.

Colbert's show did not have any goals like those found in typical political organizations. His main job per his own words was to entertain viewers (Mcgrath, 2012). If there were a main objective which he did not explicitly state himself, it would be as a news program to inform viewers about the daily fluctuations of politics across the globe. Satire was the medium through which he painted these nightly political pictures, and although it can be persuasive, it is hard to

\footnotetext{
${ }^{11}$ To be clear, Lee \& Kwak (2014) operationalize political satire as viewing a clip from The Daily Show in which Jon Stewart was using satire. However, as a show in general, this study supports that Jon Stewart used more of a direct style to communicate his messages (simply named "humor") as compared to $T C R$ 's use of implicit messaging (simply named "satire").
} 
accomplish a goal when it is not the main objective of a cause. By its very definition, news is meant to educate viewers on the current state of politics. What viewers do with that knowledge is something that can be hard to control. Although this study predicted that TCR would in fact both educate and engage viewers to participate in the democratic process, his program seems to only have been effective at the prior. This finding alone has implications for political news shows that intend to use humor and satire, and other findings from this study point to a potential problem with the way in which political news is changing viewers' political characteristics. 


\section{CHAPTER VI. INFORMED OR ACTIVE: CHOOSE ONE}

Viewing the results split between Republicans and Democrats, there seem to be two troubling conclusions. First, Democrats and Independents seem to gain political knowledge from watching $T C R$, but transitioning this knowledge into political action does not appear to occur. For those who are seeking to consume political media that will benefit their brains and their political capital through political participation, $T C R$ and satire might not be the best choice. If the show had done more political organizing efforts which had reached out to its younger and more liberally minded audience, perhaps $T C R$ viewing could have increased voter turnout and other factors which raise one's political influence. Of course, there are a million hypotheticals regarding what the show could have done better, but there seems to be a disconnect between knowledge and action for Independent and Democrat viewers. For TCR viewers, knowledge is not power.

For other media sources like cable news, the outcome for Republicans seems to be the opposite of this this general intuition. Democrats showed no statistically significant effect of television news viewing on either political knowledge or participation ${ }^{12}$. This is a problem because Democrats are not becoming more engaged with politics from television news shows, arguably one of the most pervasive forms of mass communication in America. However, the situation becomes more problematic when we look at Republicans. To be blunt, cable news makes Republicans politically act without making them more knowledgeable of the political facts $^{13}$. Only two of the five statistical models in Table 7 showed a positive and statistically

\footnotetext{
${ }^{12}$ When OLS is used, Democrats do show significant and positive effects of $A B C / C B S / N B C$ and $C N N / M S N B C / F O X$ on political participation; however, the more appropriate Poisson modeling shows each significance values of each variable far from the significance level of .05 .

${ }^{13}$ This analysis is based on the results from Poisson regression which is more appropriate for this study than OLS; however, when OLS is used, the effects of $C B S / A B C / N B C$ on political knowledge for Republicans maintain a negative effect and become statistically significant in the Pew MCS 2008 and 2012 surveys. OLS also causes the
} 
significant effect of watching $C N N / M S N B C / F O X$ on political knowledge for Republicans, and for the EGSS4 there was no significant effect. On the same EGSS4, the only political participation survey, there is a statistically significant and positive effect of cable news getting Republican viewers to participate in multiple forms of political activity. This is a disheartening combination. Although Republicans have a higher propensity to vote as shown in other studies (Shachar \& Nalebuff, 1999), this influence on the political system is happening without increased knowledge from viewing cable news. This flips the traditional saying of "knowledge is power" on its head, and it brings a serious question to this discussion. Could there be a source of news for Americans that educates and pushes people to the polls? In a sense, could an actual conservative Stephen Colbert program for Republicans accomplish this?

Conservative political satire could be a very effective medium to accomplish educational and motivational political goals for Republicans. As argued in this study, political satire gives viewers a chance to process information in an extensive and personal way. For Republicans, it could close the educational gap that cable news is not filling. So, does such a "real conservative" Colbert exist? Yes, but they are not good. Some conservative news shows have used political satire including The Flipside with Michael Loftus and Red Eye formerly featuring Greg Gutfeld. The first of these is no longer running, and Red Eye only airs at the least coveted 3 a.m. slot on Fox News. There are probably more examples, but one thing is for sure: people are still "waiting for the conservative Jon Stewart" (Morrison, 2015).

There seems to be a strange and deep connection between liberalism and humor which excludes conservatives from having a political humor show. Morrison (2015) offers up some

CNN/MSNBC/FOX variable for Republicans to maintain positive and become statistically significant in the Pew MCS 2010 and the EGSS4. Although these two groupings of news programming are different from each other, it can be argued that traditional television news programming in general does not seem to have a net positive outcome for Republicans' political knowledge regardless of which modeling technique is used. 
suggestions of why this is the case including an argument of liberal personality traits are more congruent with becoming a comedian than conservative ones, but some have gone farther indicting the very basis of conservatism as being incongruent with satire. As Alison Dagnes writes in her book A Conservative Walks into a Bar, "Conservatism supports institutions and satire aims to knock these institutions down a peg (Dagnes, 2012, p. 212)." With these two large barriers, it seems unlikely for a true conservative $T C R$ to appear, but such a show could become quite influential. For now though, liberal political humor and satire dominate this genre, and it appears certain that a "true conservative" Stephen Colbert will not be gracing the late night scene any time soon.

So what are partisans to do with political news that does not cover both bases? Unfortunately, this study provides no answers. It is a tall order to ask for political media which can both educate and inspire viewers to participate in politics; for the difficult case of America's low levels of both, it would probably require an extremely savvy and influential program. It is an important question if political humor news programs can or already are doing this, and perhaps a program does not even need humor to educate and motivate. One thing is for sure though: TCR effectively handled the educational side of the equation for Independents and Democrats. Considering Colbert was not going for either, one out of two is not bad. 


\section{CHAPTER VII. CONCLUSION}

Colbert has moved on to ventures in which he is not forced to constantly stay in his conservative character. Now on The Late Show on CBS, he frequently dips his toes back into political punditry, but it is not the same. His satire does not cut as deep. His bits are not as potent. Colbert has removed himself from being an influential source of news to becoming just another late-night talk show host, and past literature demonstrates that these shows do not do much for viewers' political sophistication. Before switching over to his new network, one must ask if Colbert had seen the academic literature testifying the positive impacts that $T C R$ held on multiple facets of American democracy. The weight and pressure alone would probably be enough to push many out and into less stressful positions, but it is honorable that Colbert would man this post in the fight for "truthiness" for almost a decade. During this time, he made Americans laugh while inadvertently making them learn about politics. His scope was endless; his tactics, hilarious. Without TCR, millions would have never learned about topics such as the Citizens United court case on campaign-finance which was beautifully taught through his creation of a super-pac named "Americans for a Better Tomorrow, Tomorrow". Colbert himself even admitted on his show on June 4th, 2014:

"Folks if you watch this show, you know I don't like to toot my own horn. As a Catholic, I was taught that self-tooting is a sin. But tonight I'm compelled to take a moment to recognize someone else's recognition of me. Jim?

[Shows CNN clip discussing an academic study about TCR.]

That's right. I did a better job informing the public about campaign-finance reform than every other news organization and CNN."

(Colbert \& Hoskinson, 2014). 
This study concurs with the study that Colbert was referencing (Hardy et al. 2014) and others which pronounce significant educational gains for both individuals and society from watching the show. It should be no surprise that he made viewers smarter about politics, but what is novel about this finding is that Colbert was even better at doing this than his former boss on The Daily Show. Colbert was willing to put his own skin in the game to create effective and influential programming. Someone willing to create an Iowa caucus ad, which can only be described as "soft-core corn porn", to show the power of money in politics had to have a powerful effect on the American political system at large.

Although he was an effective educator because of his varied satirical and over-the-top methods, Colbert was not able to do the same when it came to motivating viewers to participate in politics. Future political humor news programming can learn from the strengths and weaknesses of $T C R$ to create even more effective politically engaging news. Whether the effects of $T C R$ can be copied by future political humor shows is open for discussion. John Oliver has been able to take a large role in this space after both Colbert and Stewart left their posts, but Oliver's Last Week Tonight might not be enough. In a world where real news is now called fake news by the leader of the free world, a strong and influential voice is needed to bring truth to the lies and light to the political darkness. "Fake" news is now real news, and TCR, arguably the most fake of them all, has left the building with sweetness ${ }^{14}$ in hand.

During his last episode, Colbert left the set and into eternity singing "We'll Meet Again". It was a touching moment, and an interesting choice of song. Will we ever meet the "real" Stephen Colbert again? I personally hope we do. And that's the word.

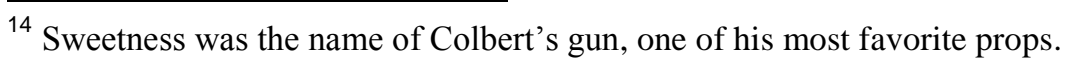




\section{REFERENCES}

American National Election Studies. (2012). EGSS4. [Datafile and code book]

Anderson, J., \& Kincaid, A. D. (2013). Media subservience and satirical subversiveness: The daily show, the colbert report, the propaganda model and the paradox of parody. Critical Studies in Media Communication, 30(3), 171-188.

Annenberg Public Policy Center. (2014). Americans know surprisingly little about their government, survey finds. (Press Release). University of Pennsylvania.

Balch, G. I. (1974). Multiple indicators in survey research: The concept "sense of political efficacy". Political Methodology, 1(2), 1-43.

Bartels, L. M. (2009). Unequal democracy: The political economy of the new gilded age. Princeton University Press.

Baumgartner, J. C. (2007). Humor on the next frontier youth, online political humor, and the JibJab effect. Social Science Computer Review, 25(3), 319-338.

Baumgartner, J. C. (2008). Polls and elections: Editorial cartoons 2.0: The effects of digital political satire on presidential candidate evaluations. Presidential Studies Quarterly, 38(4), 735-758.

Baumgartner, J. C., \& Morris, J. S. (2008). One "nation," under stephen? The effects of the colbert report on american youth. Journal of Broadcasting \& Electronic Media, 52(4), 622643.

Baumgartner, J.C., \& Morris, J. S. (2006). The daily show effect candidate evaluations, efficacy, and american youth. American Politics Research, 34(3), 341-367.

Baumgartner, J.C., \& Morris, J. S. (2012). Laughing matters: Humor and american politics in the media age. New York: Routledge. 
Becker, A. B. (2013). What about those interviews? The impact of exposure to political comedy and cable news on factual recall and anticipated political expression. International Journal of Public Opinion Research, 25(3), 344-356.

Berg, E. M., \& Lippman, L. G. (2001). Does humor in radio advertising affect recognition of novel product brand names? The Journal of General Psychology, 128(2), 194-205.

Binford, M. T. (2015). Political satire: Satirical news affinity and its relationship with political knowledge and traditional news media consumption. (Masters Thesis at Middle Tennessee State University).

Booth, J. A., \& Richard, P. B. (1998). Civil society, political capital, and democratization in central america. The Journal of Politics, 60(03), 780-800.

Boudreau, C. (2009). Making citizens smart: When do institutions improve unsophisticated citizens' decisions? Political Behavior, 31(2), 287-306.

Boyd-Barrett, O. (2004). Judith miller, the new york times, and the propaganda model. Journalism Studies, 5(4), 435-449.

Brändlin, A. (2013). The stewart and colbert effect: A comparison of young american and german viewers of american political satire shows. (Masters Thesis at University of Amsterdam).

Brinkman, D. (1968). Do editorial cartoons and editorials change opinions? Journalism \& Mass Communication Quarterly, 45(4), 724-726.

Buijzen, M., \& Valkenburg, P. M. (2004). Developing a typology of humor in audiovisual media. Media Psychology, 6(2), 147-167.doi:10.1207/s1532785xmep0602_2 
Cacioppo, J. T., Kao, C. F., Petty, R. E., \& Rodriguez, R. (1986). Central and peripheral routes to persuasion: An individual difference perspective. Journal of Personality and Social Psychology, 51(5), 1032-1043.

Campbell, A., Converse, P., Miller, W., \& Stokes, D. (1960). The american voter. Chicago: John Wiley \& Sons, Inc.

Campbell, A., Gurin, G., \& Miller, W. E. (1954). The voter decides. New York: Row, Peterson \& Co.

Cao, X., \& Brewer, P. R. (2008). Political comedy shows and public participation in politics. International Journal of Public Opinion Research, 20(1), 90-99.

Chaffee, S. H., Ward, L. S., \& Tipton, L. P. (1970). Mass communication and political socialization. Journalism \& Mass Communication Quarterly, 47(4), 647-666.

Colbert, S. (Presenter), \& Hoskinson, J. (Director). (2014, June 4, 2014). The colbert report: Season 10, episode 113. [TV Program]

Conge, P. J. (1988). The concept of political participation: Toward a definition. Comparative Politics, 20(2), 241-249. doi:10.2307/421669

Dagnes, A. (2012). A conservative walks into a bar: The politics of political humor. New York: Palgrave Macmillan.

Dahlgren, P. (2013). The political web: Media, participation and alternative democracy. Palgrave Macmillan Basingstoke.

Delli Carpini, M. X., \& Keeter, S. (1996). What americans know about politics and why it matters. Yale University Press. 
De Vreese, C. H., \& Boomgaarden, H. (2006). News, political knowledge and participation: The differential effects of news media exposure on political knowledge and participation. Acta Politica, 41(4), 317-341.

Druckman, J. N. (2001a). The implications of framing effects for citizen competence. Political Behavior, 23(3), 225-256.

Druckman, J. N. (2001b). Using credible advice to overcome framing effects. Journal of Law, Economics, \& Organization, 17(1), 62-82.

Ekman, J., \& Amnå, E. (2012). Political participation and civic engagement: Towards a new typology. Human Affairs, 22(3), 283-300.

Eveland Jr, W. P., \& Scheufele, D. A. (2000). Connecting news media use with gaps in knowledge and participation. Political Communication, 17(3), 215-237.

FairVote. (2016). Voter turnout. Retrieved from http://www.fairvote.org/voter_turnout\#voter_turnout_101

Finkel, S. E. (1985). Reciprocal effects of participation and political efficacy: A panel analysis. American Journal of Political Science, 29(4), 891-913. doi:10.2307/2111186

Finkel, S. E. (1987). The effects of participation on political efficacy and political support: Evidence from a west german panel. The Journal of Politics, 49(2), 441-464. doi: $10.2307 / 2131308$

Fowler, J. H. (2008). The colbert bump in campaign donations: More truthful than truthy. PS: Political Science \& Politics, 41(03), 533-539.

Gaines, E. (2007). The narrative semiotics of the daily show. Semiotica, 2007(166), 81-96.

Gilens, M., \& Murakawa, N. (2002). Elite cues and political decision-making. Political Decision Making, Deliberation and Participation, 6, 15-49. 
Ginsberg, B. (1982). The consequences of consent: Elections, citizen control, and popular acquiescence. Reading, Mass: Addison Wesley Publishing Company.

Gordon, S. B., \& Segura, G. M. (1997). Cross-national variation in the political sophistication of individuals: Capability or choice? The Journal of Politics, 59(01), 126-147.

Graber, D. A. (1994). Why voters fail information tests: Can the hurdles be overcome? Political Communication, 11(4), 331-346.

Griffin, J. D., \& Newman, B. (2008). Minority report: Evaluating political equality in america. Chicago: University of Chicago Press.

Gronke, P. (2000). The electorate, the campaign, and the office. Ann Arbor: University of Michigan Press.

Hardy, B. W., Gottfried, J. A., Winneg, K. M., \& Jamieson, K. H. (2014). Stephen colbert's civics lesson: How colbert super PAC taught viewers about campaign finance. Mass Communication and Society, 17(3), 329-353.

Haugtvedt, C. P., \& Petty, R. E. (1992). Personality and persuasion: Need for cognition moderates the persistence and resistance of attitude changes. Journal of Personality and Social Psychology, 63(2), 308-319.

Herman, E. S., \& Chomsky, N. (2002). Manufacturing consent: The political economy of the mass media. New York: Pantheon Books.

Hoffman, A. (2015). The john oliver effect: Political satire and political participation through social networks. (Doctoral Dissertation at Kent State University).

Hoffman, L. H., \& Thomson, T. L. (2009). The effect of television viewing on adolescents' civic participation: Political efficacy as a mediating mechanism. Journal of Broadcasting \& Electronic Media, 53(1), 3-21. 
Hoffman, L. H., \& Young, D. G. (2011). Satire, punch lines, and the nightly news: Untangling media effects on political participation. Communication Research Reports, 28(2), 159-168.

Holbert, R. L., Lambe, J. L., Dudo, A. D., \& Carlton, K. A. (2007). Primacy effects of the daily show and national TV news viewing: Young viewers, political gratifications, and internal political self-efficacy. Journal of Broadcasting \& Electronic Media, 51(1), 20-38.

Holbert, R. L., Hmielowski, J., Jain, P., Lather, J., \& Morey, A. (2011). Adding nuance to the study of political humor effects: Experimental research on juvenalian satire versus horatian satire. American Behavioral Scientist, 55(3), 187-211. doi:10.1177/0002764210392156

Hollander, B. A. (1995). The new news and the 1992 presidential campaign: Perceived vs. actual political knowledge. Journalism \& Mass Communication Quarterly, 72(4), 786-798.

Hutchings, V. L. (2003). Public opinion and democratic accountability: How citizens learn about politics. Princeton: Princeton University Press.

Jones, J. P., Baym, G., \& Day, A. (2012). Mr. stewart and mr. colbert go to washington: Television satirists outside the box. Social Research, 79(1), 33-60.

Kenski, K., \& Stroud, N. J. (2006). Connections between internet use and political efficacy, knowledge, and participation. Journal of Broadcasting \& Electronic Media, 50(2), 173-192.

Kinder, D. R., \& Kiewiet, D. R. (1981). Sociotropic politics: The american case. British Journal of Political Science, 11(02), 129-161.

LaMarre, H.L. (2013). Breaking boundaries| when parody and reality collide: Examining the effects of colbert's super pac satire on issue knowledge and policy engagement across media formats. International Journal of Communication, 7, 394-413. 
LaMarre, H. L., Landreville, K. D., \& Beam, M. A. (2009). The irony of satire political ideology and the motivation to see what you want to see in the colbert report. The International Journal of Press/Politics, 14(2), 212-231.

LaMarre, H. L., Landreville, K. D., Young, D., \& Gilkerson, N. (2014). Humor works in funny ways: Examining satirical tone as a key determinant in political humor message processing. Mass Communication and Society, 17(3), 400-423.

Lau, R. R., \& Redlawsk, D. P. (1997). Voting correctly. The American Political Science Review, 91(3), 585-598. doi:10.2307/2952076

Lau, R. R., \& Redlawsk, D. P. (2001). Advantages and disadvantages of cognitive heuristics in political decision making. American Journal of Political Science, 45(4), 951-971. doi:10.2307/2669334

Lee, H., \& Kwak, N. (2014). The affect effect of political satire: Sarcastic humor, negative emotions, and political participation. Mass Communication and Society, 17(3), 307-328.

Lewis, S. C. (2008). Where young adults intend to get news in five years. Newspaper Research Journal, 29(4), 36-52.

Lewis-Beck, M. (2008). The american voter revisited. Ann Arbor: University of Michigan Press.

Liu, Y., Shen, F., Eveland, W. P., \& Dylko, I. (2013). The impact of news use and news content characteristics on political knowledge and participation. Mass Communication and Society, 16(5), 713-737.

Lodge, M., \& Taber, C. (2000). Three steps toward a theory of motivated political reasoning. In A. Lupia, M. D. McCubbins \& S. L. Popkin (Eds.), (pp. 183-213) Cambridge Studies in Political Psychology and Public Opinion; Cambridge: Cambridge University Press. 
Lupia, A. (1994). Shortcuts versus encyclopedias: Information and voting behavior in california insurance reform elections. The American Political Science Review, 88(1), 63-76. doi: $10.2307 / 2944882$

Luskin, R. C. (1990). Explaining political sophistication. Political Behavior, 12(4), 331-361.

Mason, R. M. (1982). Participatory and workplace democracy: A theoretical development in critique of liberalism. Carbondale: Southern Illinois University Press.

McGrath, C. (2012, January 4th, 2012). How many stephen colberts are there? New York Times. Retrieved from http://www.nytimes.com/2012/01/08/magazine/stephen-colbert.html

McQuail, D. (1994). The rise of media of mass communication. In D. McQuail (Ed.), Mass communication theory: An introduction. (pp. 1-29). London: Sage.

Meddaugh, P. M. (2010). Bakhtin, colbert, and the center of discourse: Is there no "truthiness" in humor? Critical Studies in Media Communication, 27(4), 376-390.

Mendes, E. (2013). Americans down on congress, OK with own representative. Retrieved from http://www.gallup.com/poll/162362/americans-down-congress-own-representative.aspx

Mondak, J. J. (1993). Source cues and policy approval: The cognitive dynamics of public support for the reagan agenda. American Journal of Political Science, 37(1), 186-212. doi: $10.2307 / 2111529$

Morrison, O. (2015). Waiting for the conservative jon stewart: A unified theory of why political satire is biased toward, and talk radio is biased against, liberals in america. Retrieved from https://www.theatlantic.com/entertainment/archive/2015/02/why-theres-no-conservativejon-stewart/385480/ 
Nekola, M. (2006). Political participation and governance effectiveness-Does participation matter. Centre for Social and Economic Strategies (CESES), Faculty of Social Sciences, Charles University, Prague, Czech Republic,

Neuman, W. R., Just, M. R., \& Crigler, A. N. (1992). Common knowledge: News and the construction of political meaning. Chicago: University of Chicago Press.

Pateman, C. (1970). Participation and democratic theory. Cambridge: Cambridge University Press.

Peterson, D. K. (2012). The colbert bump® and the facebook ${ }^{\circledR}$ follow-through for generation snark: A test and extension of the ajzen's theory of planned behavior for 2012. Journal of Management Research, 4(3), 43.

Petty, R. E., \& Cacioppo, J. T. (1996). Attitudes and persuasion: Classic and contemporary approaches. Dubuque, IA: Westview Press.

Pew Research Center. (2008). Biennial media consumption survey 2008. [Data file and code book]

Pew Research Center. (2010). June 2010 media consumption survey. [Data file and code book] Pew Research Center. (2012). 2012 media consumption survey. [Data file and code book] Putnam, R. D. (2000). Bowling alone: The collapse and revival of american community. New York: Simon \& Schuster.

Redlawsk, D. P. (2002). Hot cognition or cool consideration? Testing the effects of motivated reasoning on political decision making. The Journal of Politics, 64(04), 1021-1044.

Robinson, J. P., \& Davis, D. K. (1990). Television news and the informed public: An information- processing approach. Journal of Communication, 40(3), 106-119. 
Sabucedo, J. M., \& Arce, C. (1991). Types of political participation: A multidimensional analysis. European Journal of Political Research, 20(1), 93-102. doi:10.1111/j.14756765.1991.tb00257.x

Schutz, C. E. (1977). Political humor: From aristophanes to sam ervin. Madison: Fairleigh Dickinson University Press.

Shachar, R., \& Nalebuff, B. (1999). Follow the leader: Theory and evidence on political participation. The American Economic Review, 89(3), 525-547.

Shaffer, S. D. (1981). A multivariate explanation of decreasing turnout in presidential elections, 1960-1976. American Journal of Political Science, 25(1), 68-95. doi:10.2307/2110913

Warner, J. (2004). George bush, jon stewart and michel foucault: Laughter as political problematization. Annual Meeting of American Political Science Association, September.

Wilkerson, R. M., \& White, K. P. (1988). Effects of the 4MAT system of instruction on students' achievement, retention, and attitudes. The Elementary School Journal, 88(4), 357-368.

Wolfinger, R., \& Rosenstone, S. (1980). Who votes?. New Haven: Yale University Press.

Young, D. G. (2013). Laughter, learning, or enlightenment? Viewing and avoidance motivations behind the daily show and the colbert report. Journal of Broadcasting \& Electronic Media, 57(2), 153-169.

Zaller, J. (1992). The nature and origins of mass opinion Cambridge university press. 


\section{APPENDIX A. EGSS4 CODING}

\section{Political Knowledge}

1. Who is the Chief Justice of the U.S. Supreme Court? - 1, John Roberts

2. Who is the Prime Minister of the U.K.? - 1, David Cameron

3. Who is the Speaker of the House of Representatives? - 1, John Boehner

\section{On which of the following does the U.S. Federal Government spend the least? - 1,} Foreign aid

\section{Political Participation}

1. Presidential Vote - Did you happen to vote in the 2008 presidential election? - No will be given a "zero", and yes a "one".

2. Primary Vote - Which one of the following best describes what you (have done so far in this upcoming election) / (did in the caucuses/primary)? "(Definitely have not voted yet in the caucus or primary), (Not completely sure whether you voted or not), and (Definitely did not vote in a [caucus/primary/caucus or primary]) will be given a "zero". (Definitely voted in person at a polling place beforelon election day), (Definitely voted by mailing a ballot to elections officials before election day), and (Definitely voted in some other way) will be given a "one".

3. Discuss Politics - Do you ever discuss politics with your friends or family? - No will be given a "zero", and yes will be given a "one".

4. Campaign Button / Sticker - During the past 12 months, have you worn a campaign button, put a campaign sticker on your car, or placed a sign in your window or in front of your house, or have you not done this in the past 12 months? - No will be given a "zero", and yes will be given a "one".

5. Donate to Campaign - During the past 12 months, have you given money to any candidate running for public office, any political party, or any other group that supported or opposed 
candidates, or have you not done this in the past 12 months? - No will be given a "zero", and yes will be given a "one”.

\section{Control Variables}

1. Age - Coded as the individual's reported age in years.

2. Male - Coded as "zero" for female and "one" for male.

3. White-Coded as "zero" for non-white and "one" for white.

4. Party Ideology - Coded as "one" for Republican, "two" for independent, and "three" for democrat. The variable is run in the main models using each as a dummy variable with Republican as the base.

5. Partisan Strength - Response to the question, "When it comes to politics, would you describe yourself, and these groups, as liberal, conservative, or neither liberal nor conservative?" Neither liberal nor conservative coded as "zero", closer to conservatives/liberals as "one", somewhat liberal/conservative as "two", very liberal/conservative as "three".

6. Education - Less than high school coded as "one", high school as "two", some college as “three”, bachelor's degree or higher as "four".

7. Income - Total household income in the past 12 months. Coded based on the 19 income categories in the c4_ppincimp variable.

8. $\mathbf{A B C} / \mathbf{C B S} / \mathbf{N B C}$ - Aggregated answer to the question, "Below are some television programs. Which of these do you watch at least once per month? ABC World News, CBS Evening News, NBC Nightly News." None coded as “zero", one program as “one”, two programs as "two", all as "three".

9. CNN/MSNBC/FOX - Aggregated answer to the question, "Below are some television programs. Which of these do you watch at least once per month? CNN Newsroom/Headline News, MSNBC Live, Fox News.” None coded as “zero”, one program as “one”, two programs as "two", all as "three". 
10. Daily Newspaper - Variable coded as the numerical answer to the question ranging from zero to seven, "During a typical week, how many days do you read news in a printed newspaper, not including sports?"

11. The Daily Show - Response to the question, "Below are some television programs. Which of these do you watch at least once per month? The Daily Show". Coded as "zero" for doesn't watch and "one" for does watch. 


\section{APPENDIX B. PEW MCS 2008 CODING}

\section{Political Knowledge}

1. Do you happen to know which political party has a majority in the U.S. House of Representatives? 1, Democrat

2. Can you tell me the name of the current U.S. Secretary of State? - 1, Condoleezza Rice/Condi/Rice

3. Who is the current prime minister of Great Britain? Is it... - 1, Gordon Brown 


\section{APPENDIX C. PEW MCS 2010 CODING}

\section{Political Knowledge}

1. Do you happen to know which political party has a majority in the U.S. House of Representatives? - 1, Democrats

2. Can you tell me which company Steve Jobs is the head of? Is it... - 1, Apple

3. Do you happen to know who Eric Holder is? Is he...- 1, The U.S Attorney General

4. Can you name the country where a recent volcanic eruption disrupted international air travel? - 1, Iceland 


\section{APPENDIX D. PEW MCS 2012 CODING}

\section{Political Knowledge}

1. Do you happen to know which political party has a majority in the U.S. House of Representatives? - 1, Republicans

2. Do you happen to know if the national unemployment rate as reported by the government is currently closer to...? - $1,8 \%$

3. Is Angela Merkel the leader of ...? - 1, Germany

4. Which person - Mitt Romney or Barack Obama - is more supportive of increasing taxes on higher income people? - 1, Barack Obama 


\section{APPENDIX E. ALL PEW MCS CONTROL VARIABLES CODING}

\section{Control Variables}

1. White - Non-white is coded as "zero" and white is coded as "one".

2. Political Party Identification - Republicans are coded as "one", Independents as "two", Democrats as "three". The variable is run in the main models using each as a dummy variable with Republican as the base.

3. Income - Response to the question, "Last year, that is in [year before survey], what was your total family income from all sources, before taxes? Just stop me when I get to the right category." Coded based on the nine categories in the INCOME variable in the datasets.

4. Age - The whole number in years of a person's age.

5. Male - Male is coded as "one" and female is "zero".

6. Education - some high school coded as "one", high school coded as "two", some college coded as "three", college grad coded as "four".

7. Partisan Strength - Response to the question, "In general, would you describe your political views as very conservative, conservative, moderate, liberal, or very liberal?" Moderate and don't know coded as "zero", liberal and conservative coded as "one", and very conservative and very liberal coded as "two".

8. $\boldsymbol{C B S / A B C / N B C}$ - Response to the question, "How often do you watch "The O'Reilly Factor" with Bill O’Reilly? Never coded as "zero", hardly ever coded as "one", sometimes coded as "two", and regularly coded as "three". [In Pew MCS 2008 when the variable when these shows were not connected into one variable and were instead asked individually for each show, this study combined the three variables (CBS, ABC, and $\mathrm{NBC}$ ) into one.]

9. $\quad C N N / M S N B C / F O X-$ Response to the question, "How often do you watch cable news channels such as CNN, MSNBC, or the Fox News CABLE Channel?" Never coded as 
"zero", hardly ever coded as "one", sometimes coded as "two", and regularly coded as "three". [When these shows were not connected into one variable and were instead asked individually for each show, this study combined the three variables (CNN, MSNBC, and FOX) into one.]

10. Daily Newspaper - Response to the question, "How often do you read a daily newspaper?" Never coded as "zero", hardly ever coded as "one", sometimes coded as "two", and regularly coded as "three"

11. [In MCS 2008] O'Reilly Factor - Response to the question, "How often do you watch “The O’Reilly Factor” with Bill O’Reilly? Never coded as “zero", hardly ever coded as “one", sometimes coded as "two", and regularly coded as "three".

12. The Daily Show - Response to the question, "How often do you watch "The Daily Show" with Jon Stewart? Never coded as "zero", hardly ever coded as "one”, sometimes coded as "two", and regularly coded as "three". 